Atmos. Chem. Phys., 13, 8915-8934, 2013

www.atmos-chem-phys.net/13/8915/2013/

doi:10.5194/acp-13-8915-2013

(C) Author(s) 2013. CC Attribution 3.0 License.

\title{
Global sea-to-air flux climatology for bromoform, dibromomethane and methyl iodide
}

F. Ziska ${ }^{1}$, B. Quack ${ }^{1}$, K. Abrahamsson ${ }^{2}$, S. D. Archer ${ }^{3,}$, E. Atlas ${ }^{4}$, T. Bell ${ }^{5}$, J. H. Butler ${ }^{6}$, L. J. Carpenter ${ }^{7}$, C. E. Jones ${ }^{7, * *}$, N. R. P. Harris ${ }^{8}$, H. Hepach ${ }^{1}$, K. G. Heumann ${ }^{9}$, C. Hughes ${ }^{10}$, J. Kuss ${ }^{11}$, K. Krüger ${ }^{1}$, P. Liss ${ }^{12}$, R. M. Moore ${ }^{13}$, A. Orlikowska ${ }^{11}$, S. Raimund ${ }^{14, * * *}$, C. E. Reeves ${ }^{12}$, W. Reifenhäuser ${ }^{15}$, A. D. Robinson ${ }^{8}$, C. Schall ${ }^{16}$, T. Tanhua ${ }^{1}$, S. Tegtmeier ${ }^{1}$, S. Turner ${ }^{12}$, L. Wang ${ }^{17}$, D. Wallace ${ }^{13}$, J. Williams ${ }^{18}$, H. Yamamoto ${ }^{19}$,**** , S. Yvon-Lewis $^{20}$, and Y. Yokouchi ${ }^{19}$

${ }^{1}$ GEOMAR, Helmholtz-Zentrum für Ozeanforschung Kiel, Kiel, Germany

${ }^{2}$ Department of Analytical and Marine Chemistry, Chalmers University of Technology and Gothenburg University, Gothenburg, Sweden

${ }^{3}$ Plymouth Marine Laboratory, Plymouth, PMI, Plymouth, UK

${ }^{4}$ Marine and Atmospheric Chemistry, Rosenstiel School of Marine and Atmospheric Science, University of Miami, MAC, Miami, USA

${ }^{5}$ Department of Earth System Science, University of California, UCI, Irvine, USA

${ }^{6}$ Earth System Research Laboratory, Global Monitoring Division, ESRL/NOAA, Boulder, USA

${ }^{7}$ Department of Chemistry, University of York, York, YO10 5DD, UK

${ }^{8}$ Department of Chemistry, University of Cambridge, Cambridge, CB2 1EW, UK, Cambridge, UK

${ }^{9}$ Institut für Anorganische Chemie und Analytische Chemie, Johannes Gutenberg-Universität, JGU, Mainz, Germany

${ }^{10}$ Laboratory for Global Marine and Atmospheric Chemistry, University of East Anglia, LGMAC/UEA, Norwich, UK

${ }^{11}$ Institut für Ostseeforschung Warnemünde, IOW, Rostock-Warnemünde, Germany

${ }^{12}$ School of Environmental Science, University of East Anglia, Norwich, UK

${ }^{13}$ Department of Oceanography, Dalhousie University, Halifax, B3H 4R2, Canada

${ }^{14}$ CNRS, UMR7144, Equipe Chim Marine, Stn Biol Roscoff, 29680 Roscoff, France

${ }^{15}$ Bayerisches Landesamt für Umwelt, Augsburg, Germany

${ }^{16}$ Fresenius Medical Care Deutschland GmbH, Frankfurterstraße 6-8, 66606 St. Wendel, Germany

${ }^{17}$ Rutgers State University of New Jersey, New Brunswick, USA

${ }^{18}$ Max Planck Institute for Chemistry, Air Chemistry Department, MPI, Mainz, Germany

${ }^{19}$ National Institute for Environmental Studies, Tsukuba, Ibaraki 305-0053, Japan

${ }^{20}$ Department of Oceanography, Texas A\&M University, College Station, USA

*now at: Bigelow Laboratory of Ocean Sciences, Maine, USA

** now at: Graduate School of Global Environmental Studies, Kyoto University, Yoshida-Honmachi, Sakyo-ku, Kyoto 606-8501, Japan

**** now at: GEOMAR, Helmholtz-Zentrum für Ozeanforschung Kiel, Kiel, Germany

**** now at: Marine Works Japan, Ltd., Oppamahigashi, Yokosuka 237-0063, Japan

Correspondence to: F. Ziska (fziska@geomar.de)

Received: 13 December 2012 - Published in Atmos. Chem. Phys. Discuss.: 27 February 2013

Revised: 14 July 2013 - Accepted: 21 July 2013 - Published: 6 September 2013 
Abstract. Volatile halogenated organic compounds containing bromine and iodine, which are naturally produced in the ocean, are involved in ozone depletion in both the troposphere and stratosphere. Three prominent compounds transporting large amounts of marine halogens into the atmosphere are bromoform $\left(\mathrm{CHBr}_{3}\right)$, dibromomethane $\left(\mathrm{CH}_{2} \mathrm{Br}_{2}\right)$ and methyl iodide $\left(\mathrm{CH}_{3} \mathrm{I}\right)$. The input of marine halogens to the stratosphere has been estimated from observations and modelling studies using low-resolution oceanic emission scenarios derived from top-down approaches. In order to improve emission inventory estimates, we calculate data-based high resolution global sea-to-air flux estimates of these compounds from surface observations within the HalOcAt (Halocarbons in the Ocean and Atmosphere) database (https://halocat.geomar.de/). Global maps of marine and atmospheric surface concentrations are derived from the data which are divided into coastal, shelf and open ocean regions. Considering physical and biogeochemical characteristics of ocean and atmosphere, the open ocean water and atmosphere data are classified into 21 regions. The available data are interpolated onto a $1^{\circ} \times 1^{\circ}$ grid while missing grid values are interpolated with latitudinal and longitudinal dependent regression techniques reflecting the compounds' distributions. With the generated surface concentration climatologies for the ocean and atmosphere, global sea-to-air concentration gradients and sea-to-air fluxes are calculated. Based on these calculations we estimate a total global flux of 1.5/2.5 $\mathrm{Gmol} \mathrm{Br} \mathrm{yr}^{-1}$ for $\mathrm{CHBr}_{3}, 0.78 / 0.98 \mathrm{Gmol} \mathrm{Br} \mathrm{yr}^{-1}$ for $\mathrm{CH}_{2} \mathrm{Br}_{2}$ and $1.24 / 1.45 \mathrm{Gmol} \mathrm{Bryr}^{-1}$ for $\mathrm{CH}_{3} \mathrm{I}$ (robust fit/ordinary least squares regression techniques). Contrary to recent studies, negative fluxes occur in each sea-to-air flux climatology, mainly in the Arctic and Antarctic regions. "Hot spots" for global polybromomethane emissions are located in the equatorial region, whereas methyl iodide emissions are enhanced in the subtropical gyre regions. Inter-annual and seasonal variation is contained within our flux calculations for all three compounds. Compared to earlier studies, our global fluxes are at the lower end of estimates, especially for bromoform. An under-representation of coastal emissions and of extreme events in our estimate might explain the mismatch between our bottom-up emission estimate and topdown approaches.

\section{Introduction}

Halogen (fluorine, chlorine, bromine, iodine)-containing volatile organic compounds play an important role in tropospheric (Vogt et al., 1999; von Glasow et al., 2004) and stratospheric chemical cycles (Solomon et al., 1994; Salawitch et al., 2005). The ocean is the largest source of natural bromine- and iodine-containing halocarbons (Quack and Wallace, 2003; Butler et al., 2007; Montzka and Reimann, 2011). When emitted into the atmosphere, these compounds, comprising mainly very short-lived species (VSLS) having an atmospheric lifetime of less than $0.5 \mathrm{yr}$, contribute to the pool of reactive halogen compounds via photochemical destruction and reaction with hydroxyl radicals (von Glasow, 2008). Deep convection, especially in the tropics, can transport VSLS above the tropical tropopause layer (Aschmann et al., 2009; Tegtmeier et al., 2012, 2013) and into the stratosphere, where they influence stratospheric ozone destruction (Salawitch et al., 2005; Sinnhuber et al., 2009). Reactive bromine and iodine are more efficient in destroying stratospheric ozone than chlorine (e.g. Chipperfield and Pyle, 1998).

The absence of global emission maps of VSLS as input for chemistry transport models and coupled chemistry climate models is a key problem for determining their role in stratospheric ozone depletion. The most widely reported shortlived halogenated compounds containing bromine in both the atmosphere and the ocean are bromoform $\left(\mathrm{CHBr}_{3}\right)$ and dibromomethane $\left(\mathrm{CH}_{2} \mathrm{Br}_{2}\right)$. Together, they may contribute $\sim 15-40 \%$ to stratospheric bromine (Montzka and Reimann, 2011), with $\mathrm{CHBr}_{3}$ considered to be the largest single source of organic bromine (Penkett et al., 1985) to the atmosphere. Its production involves marine organisms such as macroalgae and phytoplankton (Gschwend et al., 1985; Nightingale et al., 1995; Carpenter and Liss, 2000; Quack et al., 2004). $\mathrm{CH}_{2} \mathrm{Br}_{2}$ is formed in parallel with biological production of $\mathrm{CHBr}_{3}$ in seawater (Manley et al., 1992; Tokarczyk and Moore, 1994) and, therefore, generally correlates with oceanic and atmospheric bromoform (e.g. Yokouchi et al., 2005; O'Brien et al., 2009), although it occasionally shows a different pattern in the deeper ocean indicating its different cycling in the marine environment (Quack et al., 2007). Large variability in the $\mathrm{CH}_{2} \mathrm{Br}_{2}$ : $\mathrm{CHBr}_{3}$ ratio has been observed in sea water and atmosphere, while elevated concentrations of both compounds in air and water are found in coastal regions, close to macroalgae and around islands, as well as in oceanic upwelling areas (Yokouchi et al., 1997, 2005; Carpenter and Liss, 2000; Quack and Wallace, 2003; Quack et al., 2007). Seasonal variations have been observed in coastal regions (Archer et al., 2007; Orlikowska and Schulz-Bull, 2009), however the database is insufficient to resolve a global temporal dependence. Anthropogenic sources, such as water chlorination, are locally significant, but relatively small on a global scale (Quack and Wallace, 2003). There is uncertainty in the magnitude of the global emission flux, and the formation processes are poorly known. Recent studies have revealed a missing source of $\sim 5 \mathrm{pptv}$ inorganic bromine in the stratosphere, which could possibly be explained by the contribution of oceanic VSLS (Sturges et al., 2000; Sinnhuber and Folkins, 2006; Dorf et al., 2008).

Atmospheric modelling studies have derived top-down global estimates of between 5.4 and $7 \mathrm{Gmol} \mathrm{Br} \mathrm{yr}^{-1}$ for bromoform and between 0.7 and $1.4 \mathrm{Gmol} \mathrm{Bryr}^{-1}$ for dibromomethane using different atmospheric transport models (Warwick et al., 2006; Kerkweg et al., 2008; Liang et al., 
2010; Ordonez et al., 2012). Global bottom-up emission estimates based on the interpolation of surface atmospheric and oceanic measurements have yielded emission estimates of between 2.8 and $10.3 \mathrm{Gmol} \mathrm{Br} \mathrm{yr}^{-1}$ for $\mathrm{CHBr}_{3}$ and between 0.8 and $3.5 \mathrm{Gmol} \mathrm{Br} \mathrm{yr}^{-1}$ for $\mathrm{CH}_{2} \mathrm{Br}_{2}$ (Carpenter and Liss, 2000; Yokouchi et al., 2005; Quack and Wallace, 2003; Butler et al., 2007). Additionally, a parameterization for oceanic bromoform concentrations covered by a homogenous atmosphere estimates a flux of $1.45 \mathrm{Gmol} \mathrm{yr}^{-1}$ for $\mathrm{CHBr}_{3}$ between $30^{\circ} \mathrm{N}$ and $30^{\circ} \mathrm{S}$ (Palmer and Reason, 2009).

Methyl iodide is mainly emitted from the ocean and is characterized as a dominant gaseous organic iodine species in the troposphere (Carpenter, 2003; Yokouchi et al., 2008). This compound is involved in important natural iodine cycles, in several atmospheric processes such as the formation of marine aerosol (McFiggans et al., 2000), and has been suggested to contribute to stratospheric ozone depletion in case it reaches the stratosphere through deep convection (Solomon et al., 1994). Current model results of Tegtmeier et al. (2013) suggest an overall contribution of 0.04 ppt $\mathrm{CH}_{3} \mathrm{I}$ mixing ratios at the cold point and a localized mixing ratio of 0.5 ppt. Enhanced oceanic concentrations of $\mathrm{CH}_{3} \mathrm{I}$ are found in coastal areas where marine macroalgae have been identified as the dominant coastal $\mathrm{CH}_{3} \mathrm{I}$ source (e.g. Manley and Dastoor, 1988, 1992; Manley and dela Cuesta, 1997; Laturnus et al., 1998; Bondu et al., 2008). Phytoplankton, bacteria and non-biological pathways, such as photochemical degradation of dissolved organic carbon, are significant open ocean sources (Happell and Wallace, 1996; Amachi et al., 2001; Richter and Wallace, 2004; Hughes et al., 2011). Terrestrial sources, such as rice paddies and biomass burning, are suggested to contribute $30 \%$ to the total atmospheric $\mathrm{CH}_{3} \mathrm{I}$ budget (Bell et al., 2002). Modelling studies and data interpolation estimate global $\mathrm{CH}_{3} \mathrm{I}$ emissions between 2.4 and $4.3 \mathrm{Gmol} \mathrm{Iyr}^{-1}$ (Bell et al., 2002; Butler et al., 2007; Ordonez et al., 2012). Smythe-Wright et al. (2006) extrapolated a laboratory culture experiment with Prochlorococcus marinus (kind of picoplankton) to a global $\mathrm{CH}_{3} \mathrm{I}$ emission estimate of $4.2 \mathrm{Gmol} \mathrm{Iyr}^{-1}$, whereas the study of Brownell et al. (2010) disputed the result of Smythe-Wright et al. (2006) and suggests that $P$. marinus is not significant on a global scale.

This study presents the first global $1^{\circ} \times 1^{\circ}$ climatological concentration and emission maps for the three important VSLS bromoform, dibromomethane and methyl iodide based on atmospheric and oceanic surface measurements available from the HalOcAt (Halocarbons in the Ocean and Atmosphere) database project (https://halocat.geomar.de/). According to current knowledge of the compounds' distributions and possible sources, we classify the data based on physical and biogeochemical characteristics of the ocean and atmosphere. The interpolation of the missing values onto the $1^{\circ} \times 1^{\circ}$ grid with two different regression techniques is analysed. Based on the generated marine and atmospheric surface concentration maps, global climatological emissions are calculated with a commonly used sea-to-air flux parameterization applying temporally highly resolved wind speed, sea surface temperature, salinity and pressure data. The results are compared to estimates of other studies, and the temporal and spatial variability of the climatological sea-to-air flux are discussed. The aim of this study is to provide improved global sea-to-air flux maps based on in situ measurements and on known physical and biogeochemical characteristics of the ocean and atmosphere in order to reduce the uncertainties in modelling the contribution of VSLS to the stratospheric halogen budget (Hamer et al., 2013; Hossaini et al., 2013; Tegtmeier et al., 2013).

\section{Data}

In this study, $\mathrm{CHBr}_{3}, \mathrm{CH}_{2} \mathrm{Br}_{2}$ and $\mathrm{CH}_{3} \mathrm{I}$ data are extracted from the HalOcAt database (https://halocat.geomar.de/, see Supplement for a list of all data). The database currently contains about 200 contributions, comprising roughly 55400 oceanic and 476000 atmospheric measurements from a range of oceanic depths and atmospheric heights of 19 different halocarbon compounds (mainly very short-lived brominated and iodinated trace gases) from 1989 to 2011. The dataset mainly consists of data from coastal stations, ship operations and aircraft campaigns. The individual datasets are provided by the dataset creators. Since the compound distribution is too variable and the current data are too sparse to identify a robust criterion for quality check and data selection, no overall quality and intercalibration control on the database exists. Future work is planned to use common standards and perform laboratory intercalibrations (Butler et al., 2010; Jones et al., 2011). Thus, we use all available surface ocean values to a maximum depth of $10 \mathrm{~m}$ (5300 data points) and atmospheric values to a maximum height of $20 \mathrm{~m} \mathrm{(4200}$ data points) from January 1989 until August 2011 (Fig. 1) for the calculation of the climatological concentrations. For sea-to-air flux calculations (see Sect. 3.5), 6-hourly means of wind speed $(U)$, sea level pressure (SLP) and sea surface temperature (SST) are extracted from the ERA-Interim meteorological assimilation database (Dee et al., 2011) for the years $1989-2011\left(1^{\circ} \times 1^{\circ}\right)$, whereas salinity (SSS) is taken from the World Ocean Atlas 2009 (Antonov et al., 2010).

\section{Methodology}

\subsection{Approach}

The high variability of VSLS (especially for $\mathrm{CHBr}_{3}$ ) in both ocean and atmosphere is not explicable with any correlation to common parameterizations. Production pathways with associated production rates and reliable proxies for the compounds' distributions are not available. We tested correlations, multiple linear regressions and polynomial fits with biological and physical parameters (e.g. chlorophyll $a$, SST, 

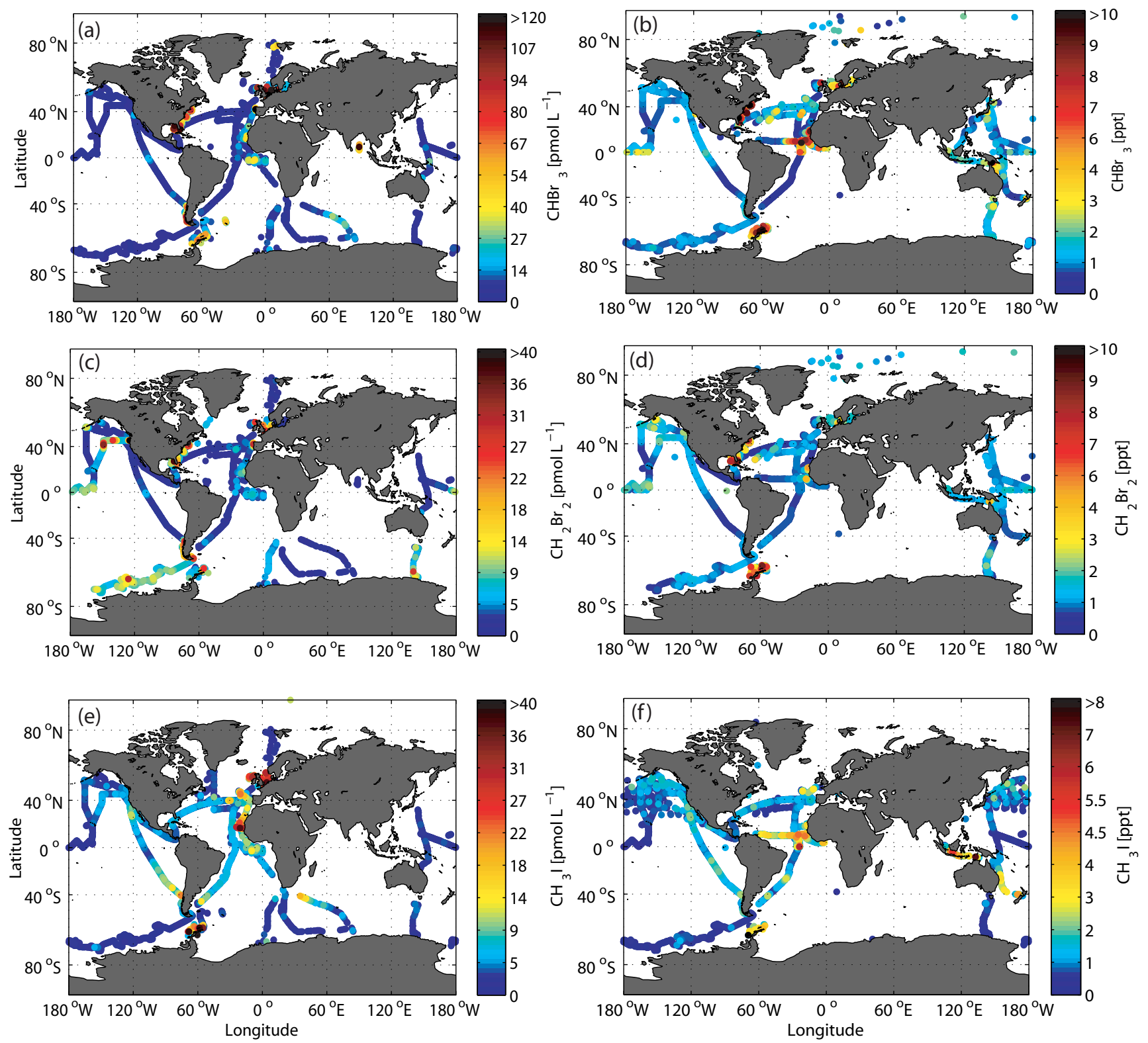

Fig. 1. Global coverage of available surface seawater measurements in pmol $\mathrm{L}^{-1}$ and atmospheric measurements in ppt for bromoform (a, b), dibromomethane (c, d) and methyl iodide (e, f) from the HalOcAt database project (data from 1989 to 2011).

SSS, SLP, mixed layer depth) to interpolate the data. Since none of the techniques provided satisfying results, we choose to simplify our approach. In order to compute climatological concentration maps, information on the compounds' distributions is extracted from the existing datasets of the HalOcAt database and the literature on source distributions. Both surface ocean and atmospheric $\mathrm{CHBr}_{3}$ concentrations are generally higher in productive tropical regions, at coast lines and close to islands, while generally lower and more homogeneous concentrations are located in the open ocean (Fig. 1). The global ocean shows a latitudinal and longitudinal variation of biological regimes, driven by circula- tion and regionally varying nutrient input as well as light conditions. Productive eastern boundary upwelling, equatorial and high latitudinal areas are separated by low productive gyre regions. We therefore separated the ocean in different latitudinal bands and applied (multiple) linear regressions between the compounds' distributions and latitude and longitude (see more details in Sect. 3.3). The linear regressions reflect the underlying coarse distribution of the data, and their longitudinal and latitudinal concentration dependence within different biogeochemical and physical regimes appears to be the current best available approach for data analysis and interpolation. This approach is independent of 
additional variables, reasonably reflecting the current knowledge about the compounds' distributions considering different biogeochemical oceanic regions and minimizes the creation of non-causal characteristics. The existing data are interpolated onto a $1^{\circ} \times 1^{\circ}$ grid. The missing grid values are filled using the latitudinal and longitudinal dependent regression techniques. The climatological oceanic and atmospheric surface concentration maps are used to calculate global fields of concentration gradients and sea-to-air fluxes.

\subsection{Classification}

All data are divided into coastal, shelf and open ocean regimes. The coastal area is defined as all first $1^{\circ} \times 1^{\circ}$ grid points next to the land mask, while the shelf regime comprises all second grid points neighbouring the coastal one. The other grid points belong to the open ocean water and atmosphere regime. The data from coastal and shelf regions are very sparse. For this reason, they are only separated between Northern Hemisphere and Southern Hemisphere.

The open ocean water data are further divided into 4 regions for each hemisphere. The inner tropics $\left(0\right.$ to $\left.5^{\circ}\right)$ include the equatorial upwelling regions with high biomass abundance and elevated $\mathrm{CHBr}_{3}$ concentrations, especially in the eastern ocean basins. The subtropical gyres, with descending water masses and hence low biological production at the surface, are identified as the second region $\left(5\right.$ to $\left.40^{\circ}\right)$. The third region comprises the temperate zones between 40 to $66^{\circ}$ with higher climatological surface chlorophyll concentrations than in the gyre region and decreasing water temperature and increasing $\mathrm{CHBr}_{3}$ concentrations towards higher latitudes. The fourth region (poleward of $66^{\circ}$ ) encompasses the polar Arctic and Antarctic with cold surface waters and occasional ice cover.

The open ocean atmosphere is classified in a slightly different way from that of the open ocean waters. The inner tropical region (here from 0 to $10^{\circ}$ ) is characterized by the intertropical convergence zone, upward motion, low pressure and deep convection. Additionally, each hemisphere is divided into 3 wind regimes: subtropics $\left(10\right.$ to $\left.30^{\circ}\right)$, midlatitudes $\left(30\right.$ to $\left.60^{\circ}\right)$ (westerlies, storm tracks) and polar regions $\left(60\right.$ to $90^{\circ}$ ), characterized by distinctive air masses, wind directions and weather conditions.

The open ocean regimes (oceanic and atmospheric) are further subdivided into the Atlantic, Pacific, Indian and Arctic basins. Thus, the HalOcAt data is sorted into 21 different regions for surface open ocean water and atmosphere (see Tables S1 and S2 in the Supplement). Gridding the data and inserting missing values is described in the following section. Dibromomethane has been reported to have similar source regions as $\mathrm{CHBr}_{3}$, (Yokouchi et al., 2005; O'Brien et al., 2009), while methyl iodide is reported to also have coastal, planktonic and photochemical sources (Hughes et al., 2011; Moore et al., 1994; Richter and Wallace, 2004). Both compounds are also tight to unrevealed direct or indirect biolog- ical processes. Thus, we divide the $\mathrm{CH}_{2} \mathrm{Br}_{2}$ and $\mathrm{CH}_{3} \mathrm{I}$ data between the regions in the same way as we have classified the $\mathrm{CHBr}_{3}$ data. The data density for dibromomethane and methyl iodide is equivalent to that of bromoform (Fig. 1).

\subsection{Objective mapping}

The original, irregular measurements from the HalOcAt database are transferred to a uniform global $1^{\circ} \times 1^{\circ}$ grid using a Gaussian interpolation. Based on this technique the value at each grid point is calculated with the measurements located in a defined Gaussian range. The Gaussian bell radius is $3^{\circ}$ for the surface open ocean water and atmosphere data and $1^{\circ}$ for the coast and shelf region. The wider radius for the open ocean regimes are caused by the higher homogeneity of the data in this region. This kind of interpolation takes the spatial variance of the measurements into account. The smaller the distance between a given data point and the grid point, the greater is its weighting in the grid point calculation (Daley, 1991) (see Supplement for a list of all calculated atmospheric and oceanic grid points based on objective mapping). For grid points where no measurements are available within the Gaussian bell area, no concentration data can be calculated directly and a linear regression needs to be applied.

\subsection{Linear regression}

Data gaps on the $1^{\circ} \times 1^{\circ}$ grid are filled based on a multiple linear regression technique using the original dataset, applying the functional relationship between latitude and longitude as predictor variables, $x_{1}$ and $x_{2}$, and compound concentration as the response variable, $y$ (Fig. 2, for specific details see Sect. 3.5).

The regression coefficients for each defined oceanic and atmospheric region are given in Tables S1 and S2 in the Supplement. For regions where the spatial coverage of the data is extremely poor, a first order regression based on the latitude variable only is used. For regions without data or in case the interpolation does not produce reasonable results (e.g. concentrations calculated with the regression are negative), the linear regression of neighbouring open ocean regions of the same latitudinal band is used to fill the data gaps, assuming similar physical and biogeochemical conditions. For example, no data exist for the tropical Indian Ocean $\left(0-5^{\circ} \mathrm{N}\right)$, thus, open ocean data from the tropical Atlantic and Pacific $\left(0-5^{\circ} \mathrm{N}\right)$ are used to determine the missing values. Since data coverage in coastal and shelf regions is low, the regression coefficients are calculated over each entire hemisphere. Additionally, we apply the root mean square error (RMSE), calculated as the difference between the predicted values and the observed data, as a measure of accuracy. A small RMSE reflects a low bias and variance of the predicted values, with zero indicating that the regression techniques predict the observations perfectly. 

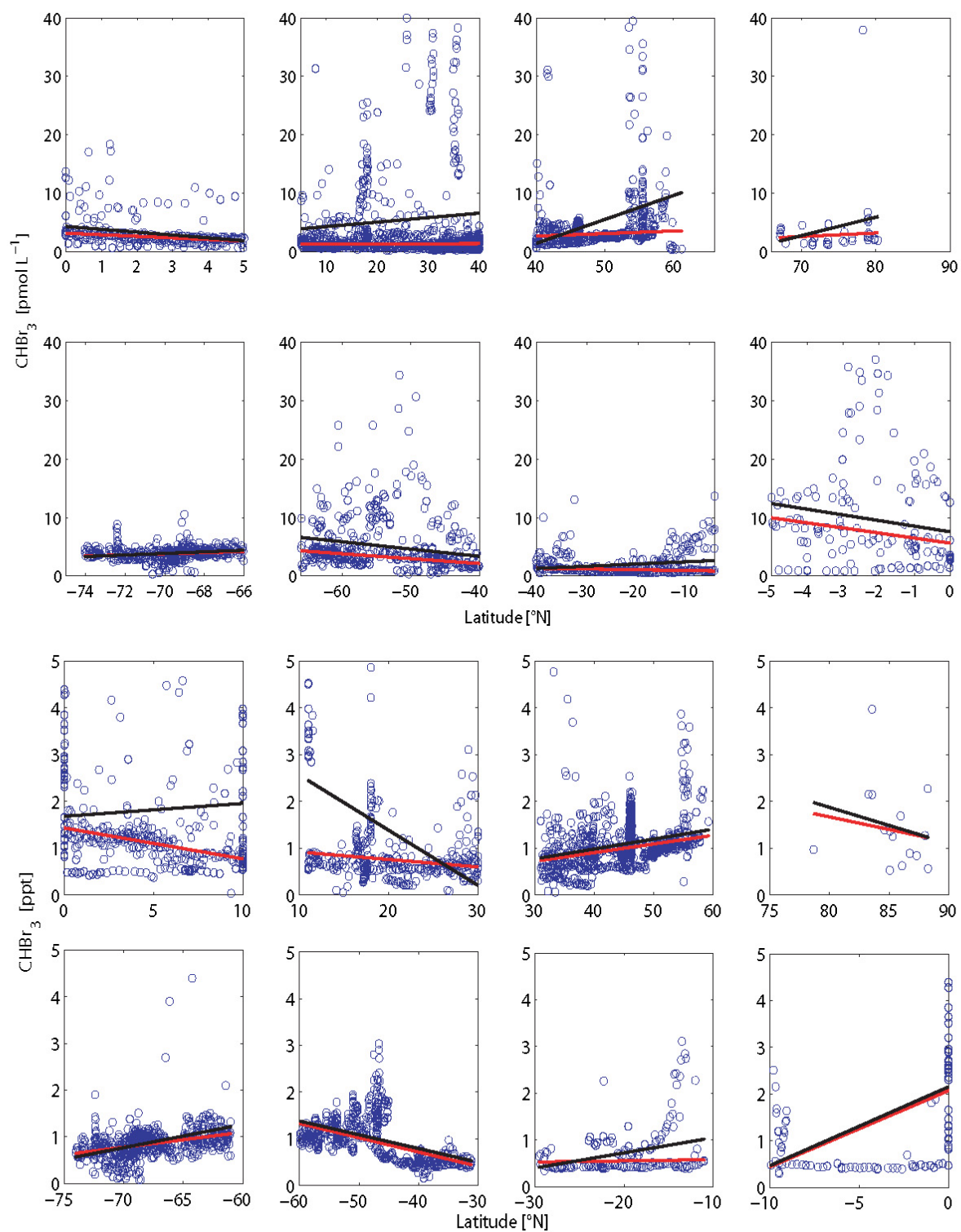

Fig. 2. Latitudinal distribution of open ocean water (a) $\left(\mathrm{pmol} \mathrm{L}^{-1}\right)$ and atmosphere (b) (ppt) bromoform concentrations (blue circles) classified in eight different latitudinal bands. The robust fit (RF) (red line) and ordinary least squares (OLS) (black line) regression analyses are included.

\subsection{Robust fit vs. ordinary least squares}

In our study, two different regression techniques are applied. The ordinary least squares (OLS) technique contains the least squares method. This means that the sum of squared deviations between the empirical $y$ values in the dataset and the predicted linear approximation is minimized.

The second method for calculating regression coefficients is the robust fit (RF) technique which is especially used for not normally distributed values. A regression analysis is robust if it is not sensitive to outliers. The calculation of the robust coefficients is based on the iteratively reweighted least squares process. In the first iteration each data point has equal weight and the model coefficients are estimated using ordinary least squares. In the following iterations, the weighting of the data points is recalculated so that the distant data points from the model regression from the previous iteration are given lower weight. This process continues until the model coefficients are within a predefined range. Our calculations are based on the most common general method of robust regression, the "M-estimation" introduced by Huber (1964).

Both regression methods are shown in Fig. 2 for all latitudinal divided open ocean water and atmospheric measurements for bromoform. The RF regression lines (red) are lower than the OLS (black) and occasionally show different 

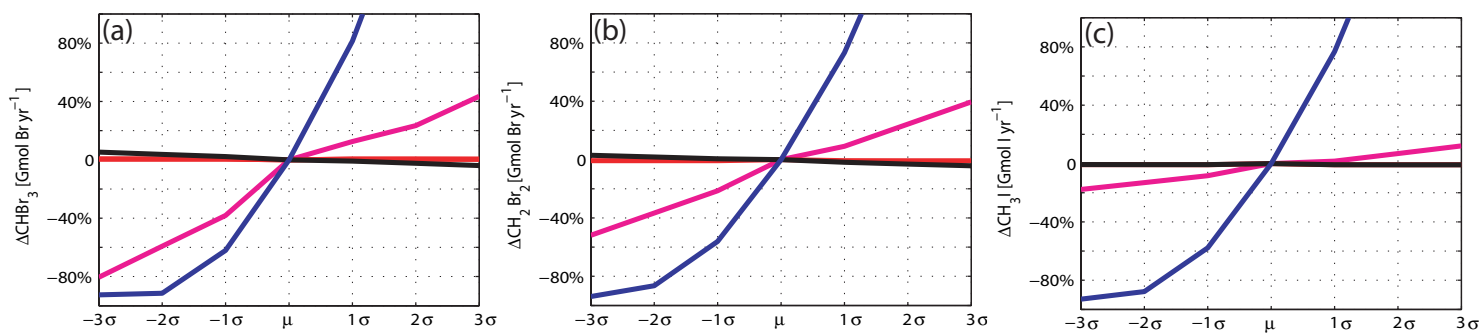

Fig. 3. The percentage change of the global oceanic emission for bromoform (a), dibromomethane (b), both in $\mathrm{Gmol} \mathrm{Bryr}^{-1}$, and methyl iodide (c), in $\mathrm{Gmol} \mathrm{Iyr}^{-1}$, based on individual input parameters: wind speed (blue), sea surface temperature (magenta), sea surface salinity (red) and sea level pressure (black). The input parameters are individually increased and decreased by their multiple standard deviations $(-3 \sigma$ to $3 \sigma)$ while the other input parameters remain fixed ( $\mu$ presents the oceanic emission using the mean input parameters).

trends. The reason for the large deviation between the RF and OLS regression is the different weighting of outliers. Outliers crucially influence the value of the OLS slope, whereas the RF regression is located at the largest data density and reduces the influence of outliers. While the RF captures background values, the OLS technique indicates the variability of the data. Based on the obtained concentration maps, global fluxes are calculated and compared to literature values (see Supplement for a list of all calculated atmospheric and oceanic grid points based on linear regression and objective mapping as well as on linear regression only).

\subsection{Air-sea gas exchange and input parameters}

Fluxes ( $F$ in pmol cm h${ }^{-1}$ ) across the sea-air interface are generally calculated as the product of the sea-to-air concentration difference and a gas exchange velocity. The partitioning of a gas between the water and gas phase is described by the dimensionless Henry's law constant $(H)$ which highly depends on temperature and the molecular structure of the species. For our calculations, the Henry's law constants of Moore et al. (1995a, b) are used. The atmospheric mixing ratios $\left(C_{\mathrm{m}}\right.$ in ppt) are converted to equilibrium water concentrations $\left(C_{\mathrm{a}}\right.$ in pmol $\left.\mathrm{L}^{-1}\right)$ and the deviation from the actual measured water concentration $\left(C_{\mathrm{w}}\right.$ in pmol L ${ }^{-1}$ ) describes the driving concentration gradient. The sea-to-air flux is negative if the transport is from the atmosphere to the ocean.

$F=k\left(C_{\mathrm{w}}-C_{\mathrm{a}} H^{-1}\right)$

$C_{\mathrm{a}}=C_{\mathrm{m}} \cdot \mathrm{SLP} /(\mathrm{SST}+273.15) / 83.137$

$H=\exp (-4973 /(\mathrm{SST}+273.15)+13.16)$ for $\mathrm{CHBr}_{3}$

Several parameterizations for the air-sea gas exchange exist in the literature, which express the relationship between the gas exchange velocity $\left(k\right.$ in $\left.\mathrm{cm} \mathrm{h}^{-1}\right)$ and wind speed (e.g. Liss and Merlivat, 1986; Wanninkhof, 1992; Wanninkhof and McGillis, 1999; Nightingale et al., 2000). Experiments have shown that the dominant parameter influencing $k$ is the wind speed. We chose to calculate the transfer coefficients based on the parameterization from Nightingale et al. (2000) with corrections for the water temperature and a Schmidt number $(S c)$ dependence for each gas (Quack and Wallace, 2003; Johnson, 2010).

$k=\left(0.222 U^{2}+0.333 U\right) \operatorname{sqrt}\left(660 S c^{-1}\right)$

The dimensionless Schmidt number is the ratio of the diffusion coefficient of the compound $\left(D\right.$ in $\left.\mathrm{cm}^{2} \mathrm{~s}^{-1}\right)$ of interest and the kinematic viscosity ( $v$ in $\mathrm{cm}^{2} \mathrm{~s}^{-1}$ ) of sea water, and depends mainly on the temperature and the salinity.

$$
\begin{aligned}
S c & =v / D \\
D & =\left(193 \times 10^{-10} \times \mathrm{SST}^{2}+1686 \times 10^{-10} \times \mathrm{SST}\right. \\
& \left.+403.42 \times 10^{-8}\right) \text { for } \mathrm{CHBr}_{3}
\end{aligned}
$$

The diffusion coefficients for the compounds were calculated according to Quack and Wallace (2003).

The gas exchange velocity and concentration gradient are dependent on SST, SSS, $U$ and SLP as input parameters. During the initial stages of this study, we used climatological mean values (1989-2011) of the input parameters for our calculation of the global climatological emission estimates. A sensitivity study demonstrates how changes in the input parameters (climatological means) affect the global flux calculation for bromoform, dibromomethane and methyl iodide (Fig. 3). Each input parameter is individually increased and decreased by their multiple standard deviations $(-3 \sigma$ to $3 \sigma)$ while the other input parameters remain fixed. The standard deviations are calculated for every grid point for the years 1989-2011. This study shows the importance of each input parameter for the flux variance. Sea surface salinity and sea level pressure affects the VSLS emission calculations least compared with the other parameters (Fig. 3). Changes in wind speed and sea surface temperature have strong influences on the bromoform sea-to-air flux. In general, a reduction/enhancement of the wind speed is directly accompanied by a decrease/increase in air-sea gas exchange coefficients, and higher/lower sea surface temperature leads to an increase/decrease of the concentration gradients as well as the air-sea gas exchange coefficients (Schmidt number). 
The dependencies of the global dibromomethane emission variability on the individual input parameters are the same as described for bromoform. The global methyl iodide emissions are mainly influenced by variations of the wind speed, while the other parameters have less effect. The sensitivity study shows that marginal changes of the input parameters can lead to a significant variation of the global flux estimate.

Averaging over a long time period when producing climatological means involves smoothing extreme values, which is especially relevant for the wind speed (Bates and Merlivat, 2001). Since the air-sea gas exchange coefficient has a non-linear dependence on wind speed, the application of averaged data fields causes a bias towards a lower flux when compared to using instantaneous winds and averaging the emission maps afterwards (Chapman et al., 2002; Kettle and Merchant, 2005). To reduce the bias, we apply the highest available temporal resolution of the input parameters and calculate 6-hourly global emissions with 6-hourly means of $U$, SST, SLP and monthly means for the SSS (from January 1989 to December 2011). Finally, we sum the emissions for each month, calculate monthly average emissions over the twenty-one years and summarise these twelve averages to obtain the climatological annual emission.

\section{Results and discussion}

Marine $\left(\mathrm{pmol} \mathrm{L}^{-1}\right)$ and atmospheric (ppt) global surface concentration maps of bromoform, dibromomethane and methyl iodide calculated with the RF regression are shown in Fig. 4 (surface ocean concentrations and mixing ratios calculated with the OLS technique are illustrated in the Supplement). Based on the RF and OLS marine and atmospheric concentration maps, global sea-to-air flux climatologies are calculated (Fig. 5).

\subsection{Climatological concentration maps of $\mathrm{CHBr}_{3}$ and $\mathrm{CH}_{2} \mathrm{Br}_{2}$}

Marine surface concentrations of bromoform (Fig. 4) are higher in the equatorial region $\left(\sim 6 \mathrm{pmol} \mathrm{L}^{-1}\right)$, upwelling areas (e.g. the Mauritanian upwelling region $\sim 21 \mathrm{pmol} \mathrm{L}^{-1}$ ), near coastal areas $\left(\sim 17-42 \mathrm{pmol} \mathrm{L}^{-1}\right)$ and in shelf regions $\left(\sim 8-32 \mathrm{pmol} \mathrm{L}^{-1}\right)$, consistent with macroalgal and anthropogenic sources along the coast lines as well as biological sources in upwelling areas (Carpenter and Liss, 2000; Quack and Wallace, 2003; Yokouchi et al., 2005; Quack et al., 2007; Liu et al., 2011). The coastal and shelf areas both show a positive latitudinal sea surface concentration gradient for bromoform and dibromomethane towards the polar regions. The coastal sea surface concentrations of bromoform are on average twice as high as in the shelf region. The open ocean generally has homogeneous concentrations between 0.5 and $4 \mathrm{pmol} \mathrm{L}^{-1}$. Lower values are located especially in the sub- tropical gyres $\left(\sim 0.5-1 \mathrm{pmol} \mathrm{L}^{-1}\right)$, most distinctly in the Atlantic, North Pacific and southern Indian Ocean.

Estimating global concentration maps based on an identified linear relationship is difficult in regions with sparse or missing data (e.g. Indian Ocean). Atlantic and Pacific Ocean data must be used to fill the data gap in the Indian Ocean, since no measurements exist there. Thus, we expect similar concentrations as in the other oceans. One dataset is available for the northern Indian Ocean (Yamamoto et al., 2001). The few measurements of bromoform in the Bay of Bengal are unusually high $\left(>50 \mathrm{pmol} \mathrm{L}^{-1}\right)$ for an open ocean area. We decided to not include these outliers in our analysis, since our method would possibly overestimate water concentrations in the entire northern Indian Ocean using these data. The high concentrations in the equatorial region (the product of the other two basins) are approximately collocated with the upwelling season during the northeast monsoon, indicating higher productivity (Schott et al., 2002). The global ocean, and especially the Indian and Arctic, is data poor, and requires further sampling and evaluation to improve the predictions. Atmospheric surface mixing ratios of bromoform show similar distribution patterns. Higher atmospheric mixing ratios are located in the equatorial regions (1-3 ppt), around coastlines $(\sim 1-10 \mathrm{ppt})$ and upwelling regions $(10-17 \mathrm{ppt})$, as well as in the northern Atlantic ( $12-21 \mathrm{ppt})$, while lower mixing ratios are found above the subtropical gyres $(\sim 0.2-$ $0.8 \mathrm{ppt})$.

The global surface oceanic concentration map of dibromomethane shows similar patterns as bromoform. Enhanced oceanic surface concentrations are located around the equatorial region $\left(\sim 6-9 \mathrm{pmol} \mathrm{L}^{-1}\right)$, while low concentrations occur in the subtropical gyres $\left(1-2 \mathrm{pmol} \mathrm{L}^{-1}\right)$, similar to $\mathrm{CHBr}_{3}$ in distribution, but with higher values. Dibromomethane concentrations in the coastal regions are significantly lower than those for bromoform. Distant from the coastal source regions $\mathrm{CH}_{2} \mathrm{Br}_{2}$ is mostly elevated in the atmosphere relative to $\mathrm{CHBr}_{3}$, because it has a longer atmospheric lifetime than $\mathrm{CHBr}_{3}$ (e.g. Brinckmann et al., 2012) $\left(\mathrm{CH}_{2} \mathrm{Br}_{2}=0.33 \mathrm{yr}, \mathrm{CHBr}_{3}=0.07 \mathrm{yr}\right.$, (Warneck and Williams, 2012).

Elevated marine dibromomethane concentrations are found in the Southern Ocean $\left(4-6 \mathrm{pmol} \mathrm{L}^{-1}\right)$. This area is characterized by several circumpolar currents separated by frontal systems, with seasonally varying ice coverage, and is known to experience enhanced biological production (Smith and Nelson, 1985). Sea-ice retreat and the onset of microalgae blooms have been related to an increase in marine surface bromocarbon concentrations (Hughes et al., 2009). However, this strong increase of $\mathrm{CH}_{2} \mathrm{Br}_{2}$ is currently not understood.

The climatological maps represent annual average values that may underestimate seasonal and short-term variations (Hepach et al., 2013; Fuhlbrügge et al., 2013). These variations currently cannot be reflected in the model, since knowledge about production processes and the influence of environmental values on the concentrations is incomplete. 


\subsection{Climatological concentration maps of $\mathrm{CH}_{3} \mathrm{I}$}

The same classification and interpolation technique used for the bromocarbons reveal elevated marine and atmospheric concentrations of methyl iodide $\left(2-9 \mathrm{pmol} \mathrm{L}^{-1}, 0.3-1.5 \mathrm{ppt}\right)$ in the subtropical gyre regions of both hemispheres (Fig. 4). This is in contrast to the oceanic concentration maps of bromoform and dibromomethane, and is in agreement with reported production processes, such as photochemical oxidation of dissolved organic matter and iodide, as well as production from cyanobacteria (e.g. Richter and Wallace, 2004; Smythe-Wright et al., 2006).

Additionally, enhanced oceanic concentrations and atmospheric mixing ratios are found in the upwelling region off Mauritania and near the coastlines north of $40^{\circ}$ $\left(\sim 9 \mathrm{pmol} \mathrm{L}^{-1}\right)$. Here in the region of offshore trade winds and dust export, the atmospheric methyl iodide from the ocean may be supplemented by input from land sources (Sive et al., 2007) as elevated air concentrations have been noted to be associated with dust events (Williams et al., 2007). The sharp concentration increase towards the coast, as observed for bromoform and dibromomethane, does not exist for methyl iodide. The open ocean concentrations are generally higher than the coastal values, except for the Northern Hemisphere. The elevated coastal oceanic concentrations might be due to the occurrence of macroalgae and anthropogenic land sources (e.g. Laturnus et al., 1998; Bondu et al., 2008) or to elevated levels of dissolved organic material (DOM) (e.g. Manley et al., 1992; Bell et al., 2002). The polar regions show generally homogenous and low concentrations of methyl iodide (Antarctic: $\sim 0.3 \mathrm{ppt}, \sim 1.5 \mathrm{pmol} \mathrm{L}^{-1}$; Arctic: $\sim 1 \mathrm{ppt}$ and $\left.\sim 0.3 \mathrm{pmol} \mathrm{L}^{-1}\right)$.

\subsection{Climatological emission maps of $\mathrm{CHBr}_{3}$ and $\mathrm{CH}_{2} \mathrm{Br}_{2}$}

Elevated bromoform fluxes from the ocean to the atmosphere are generally found close to coastlines, in equatorial and eastern boundary upwelling regions (e.g. the Mauritanian upwelling region) and a wide region of the southern Pacific (subtropical gyre). Very high sea-to-air fluxes $\left(>1500 \mathrm{pmol} \mathrm{m}^{-2} \mathrm{~h}^{-1}\right)$ also occur in the Bay of Bengal, the Gulf of Mexico, the North Sea and the east coast of North America.

While they cover $16 \%$ of the world ocean area, the coastal and shelf regions, with their high biological productivity, have enhanced concentrations of bromoform and dibromomethane and account for $67 / 78(\mathrm{RF} / \mathrm{OLS}) \%$ of total $\mathrm{Br}$ emission attributable to $\mathrm{CHBr}_{3}$ and $22 / 24 \%$ of that attributable to $\mathrm{CH}_{2} \mathrm{Br}_{2}$. Most of the open ocean appears almost in equilibrium with the atmosphere, especially in the subtropical gyre regions. $\mathrm{A} \mathrm{CHBr}_{3}$ flux from the atmosphere to the ocean is seen in the entire Southern Ocean, the northern part of the Pacific and in some parts of the North Atlantic (e.g. east of North America).
Our open ocean flux of $\mathrm{CHBr}_{3}$ is about $25 \%$ of the global sea-to-air flux estimate, which is in agreement with the $20 \%$ calculated by Butler et al. (2007) and the $33 \%$ of Quack and Wallace (2003). This underlines that the coast and shelf regions play a significant role in the global bromoform budget. The tropics $\left(20^{\circ} \mathrm{N}\right.$ to $20^{\circ} \mathrm{S}$, including open ocean, shelf and coastal area) represent the region with the highest bromoform emissions of $44 / 55 \%$ (Table 3 ). This is in agreement with the top-down approach of $55.6 \%$ between $20^{\circ} \mathrm{N}$ to $20^{\circ} \mathrm{S}$ published by Ordonez et al. (2012) and of $37.7 \%$ for $10^{\circ} \mathrm{N}$ to $10^{\circ} \mathrm{S}$ from Liang et al. (2010). A decrease in the total emission towards the polar region is visible. Hence, the tropics are a "hot spot" for bromoform emissions.

Comparable with the sea-to-air fluxes based on the RF analysis, the emissions using the OLS method shows enhanced sea-to-air fluxes in the North Atlantic and all gyre regions, and an elevated sink in the Arctic region (Fig. 5). We estimate a global positive sea-to-air flux for $\mathrm{CHBr}_{3}$ of $\sim 2.06 \mathrm{Gmol} \mathrm{Br} \mathrm{yr}^{-1}$ (RF), $\sim 2.96 \mathrm{Gmol} \mathrm{Br} \mathrm{yr}^{-1}$ (OLS); and a global sink, air-to-sea flux, for $\mathrm{CHBr}_{3}$ of $\sim 0.56 \mathrm{Gmol} \mathrm{Br} \mathrm{yr}^{-1}$ (RF), $\sim 0.47 \mathrm{Gmol} \mathrm{Br} \mathrm{yr}^{-1}$ (OLS).

Differences between the distribution of source and sink regions and of $\mathrm{CH}_{2} \mathrm{Br}_{2}$ emissions calculated with the $\mathrm{RF}$ and OLS regression are less pronounced than those of $\mathrm{CHBr}_{3}$ (Fig. 5). The Arctic Ocean acts mainly as a sink for atmospheric $\mathrm{CH}_{2} \mathrm{Br}_{2}$, most likely because of the low sea surface temperatures, low water concentrations and higher air concentrations. The Southern Ocean (south of $50^{\circ} \mathrm{S}$ ) acts as a source to the atmosphere. The OLS based emissions show an enhanced source region in the southern Pacific due to elevated marine surface concentrations. We estimate a positive global $\mathrm{CH}_{2} \mathrm{Br}_{2}$ sea-to-air flux of $\sim 0.89 \mathrm{Gmol} \mathrm{Br} \mathrm{yr}^{-1}$ (RF), $\sim 1.09 \mathrm{Gmol} \mathrm{Br} \mathrm{yr}^{-1}$ (OLS); and an air-to-sea flux of $\sim 0.12 \mathrm{Gmol} \mathrm{Br} \mathrm{yr}^{-1}$ (RF), $\sim 0.11 \mathrm{Gmol} \mathrm{Br} \mathrm{yr}^{-1}$ (OLS).

Our total open ocean flux of $0.6-0.76 \mathrm{Gmol} \mathrm{Br}$ $\left(\mathrm{CH}_{2} \mathrm{Br}_{2}\right) \mathrm{yr}^{-1}$ is in agreement with the estimates of $\sim 0.7 \mathrm{Gmol} \mathrm{Bryr}^{-1}$ given by Ko et al. (2003) and $0.6 \mathrm{Gmol} \mathrm{Bryr}^{-1}$ given by Butler et al. (2007). The coast and shelf regions play a minor role for the global $\mathrm{CH}_{2} \mathrm{Br}_{2}$ budget compared to the open ocean, which contributes $\sim 77 \% \mathrm{Gmol} \mathrm{Bryr}^{-1}$. The global emission distribution for $\mathrm{CH}_{2} \mathrm{Br}_{2}$ and $\mathrm{CHBr}_{3}$ is similar in the midlatitudes and the tropics. (Table 3). Enhanced source regions for the atmosphere are found in the tropical area contributing about $44 / 49 \%$ between $20^{\circ} \mathrm{N}$ and $20^{\circ} \mathrm{S}$. This is lower compared with the study of Ordonez et al. (2012) who calculated a contribution of $63.1 \%$ from $20^{\circ} \mathrm{N}$ to $20^{\circ} \mathrm{S}$. The $\mathrm{CH}_{2} \mathrm{Br}_{2}$ emissions decrease towards the polar regions.

\subsection{Climatological emission maps of $\mathrm{CH}_{3} \mathrm{I}$}

The global emissions of $\mathrm{CH}_{3} \mathrm{I}$ reveal an opposite pattern compared with $\mathrm{CHBr}_{3}$ and $\mathrm{CH}_{2} \mathrm{Br}_{2}$ (Fig. 5). The main difference is the enhanced emission in the subtropical gyre regions. 
(a)
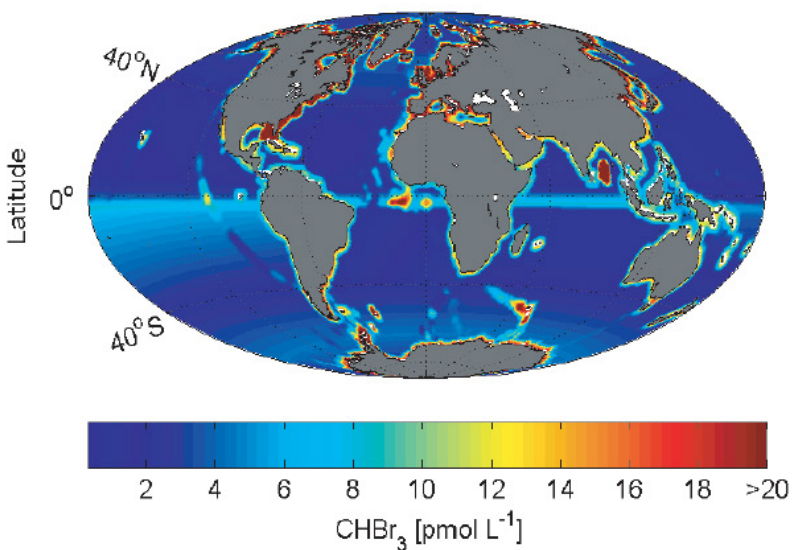

(c)
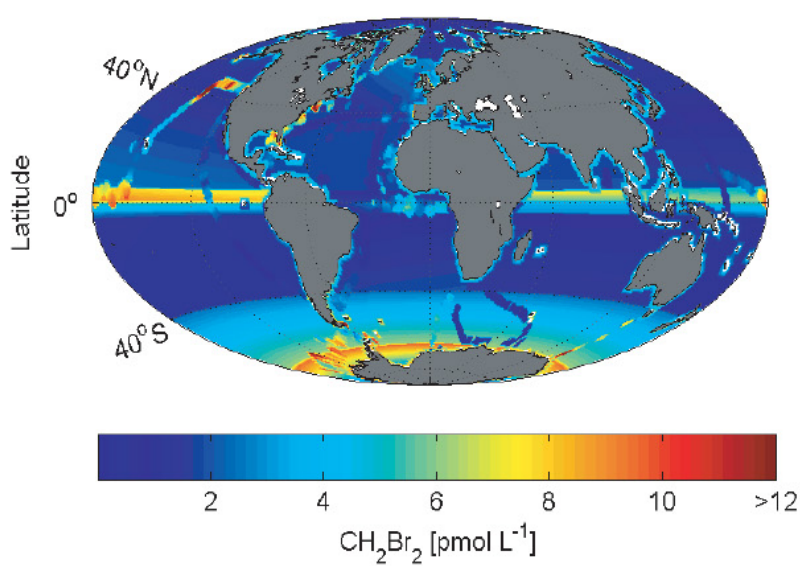

(e)

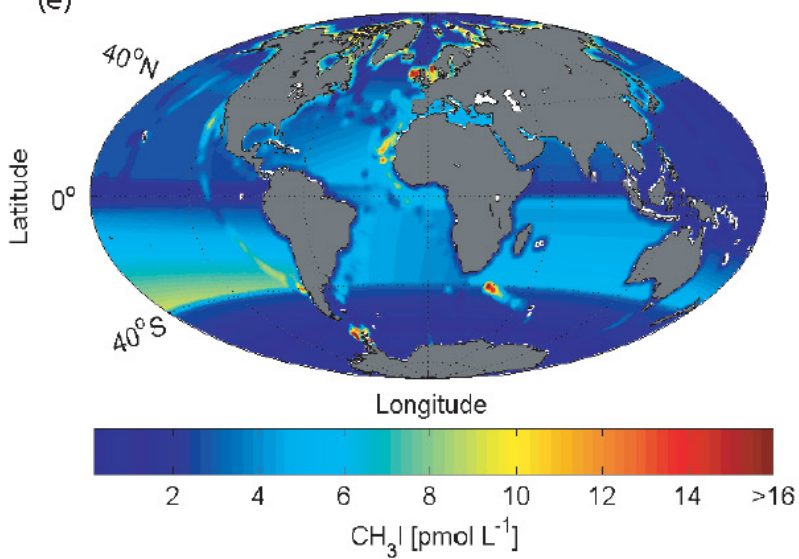

(b)
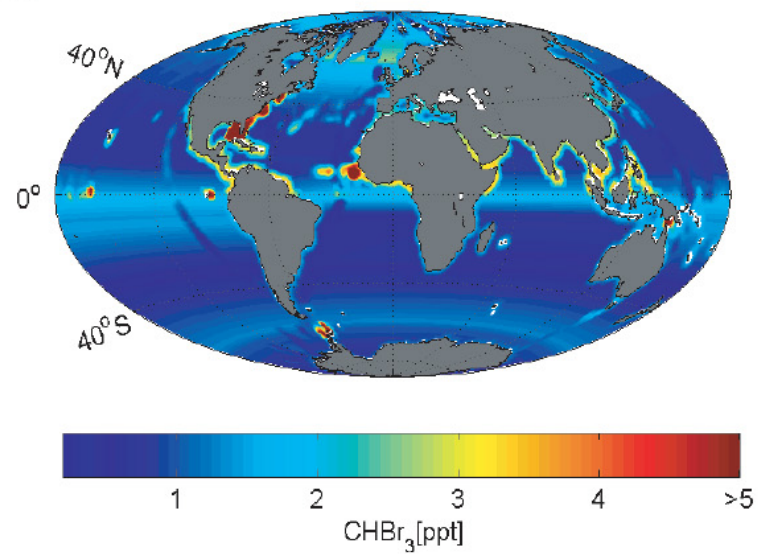

(d)
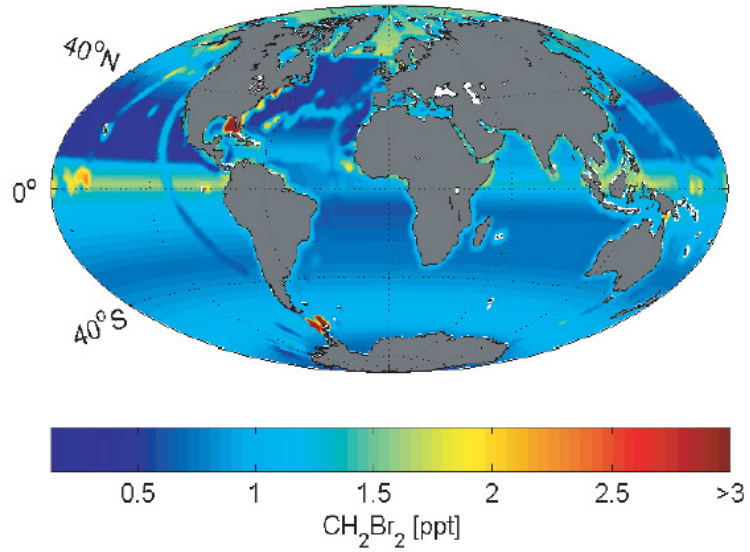

(f)

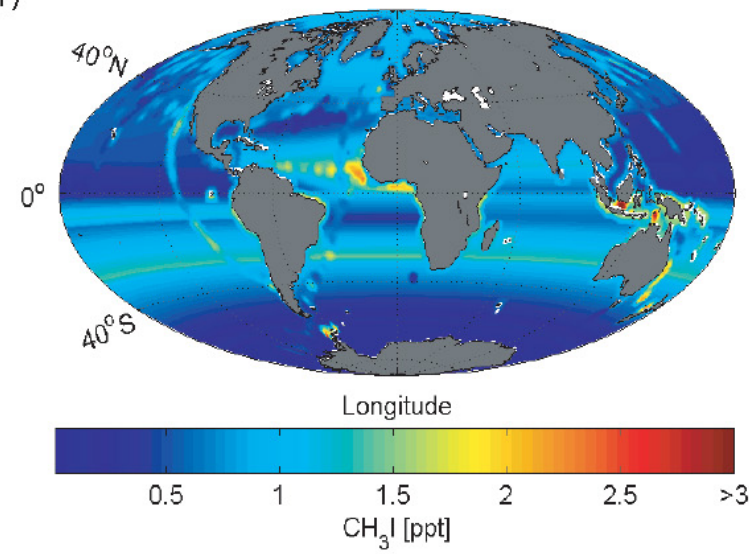

Fig. 4. Global maps of marine concentrations (pmol L ${ }^{-1}$ ) and atmospheric mixing ratios (ppt) for bromoform (a, b), dibromomethane (c, d) and methyl iodide (e, f) based on the robust fit $(\mathrm{RF})$ regression analyses. The concentration maps calculated with the OLS method are included in the Supplement (Fig. S3). 
(a)
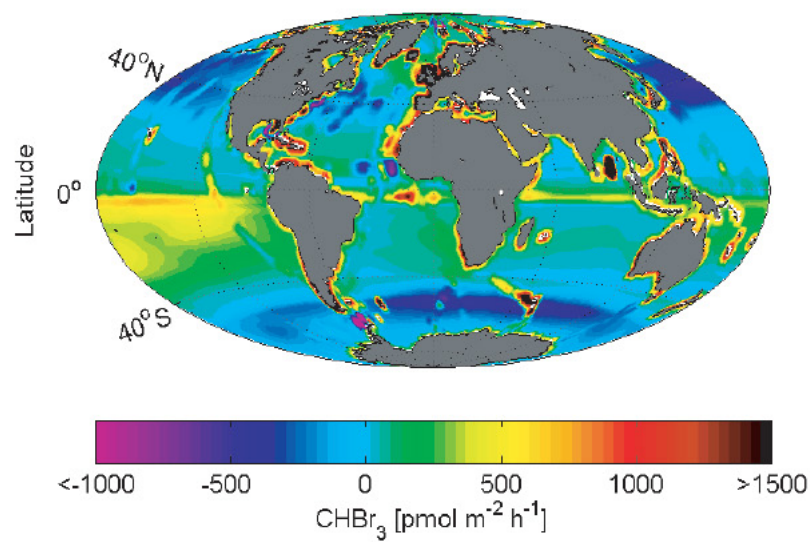

(c)
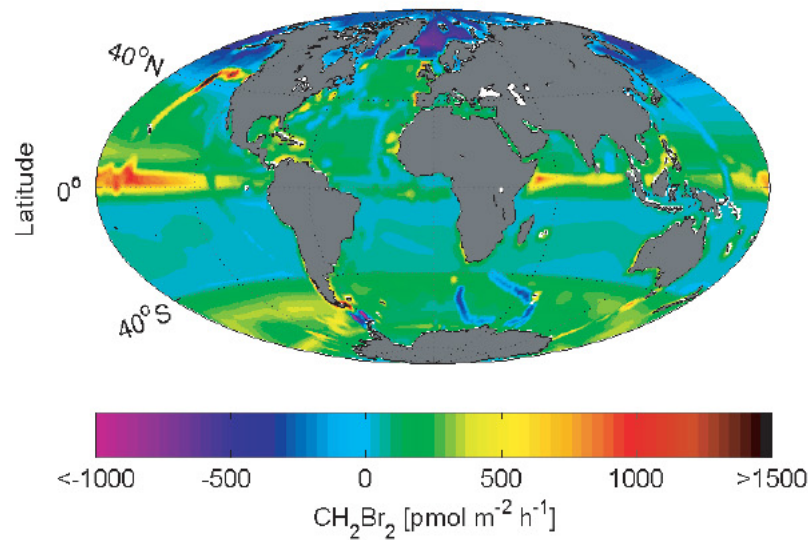

(e)

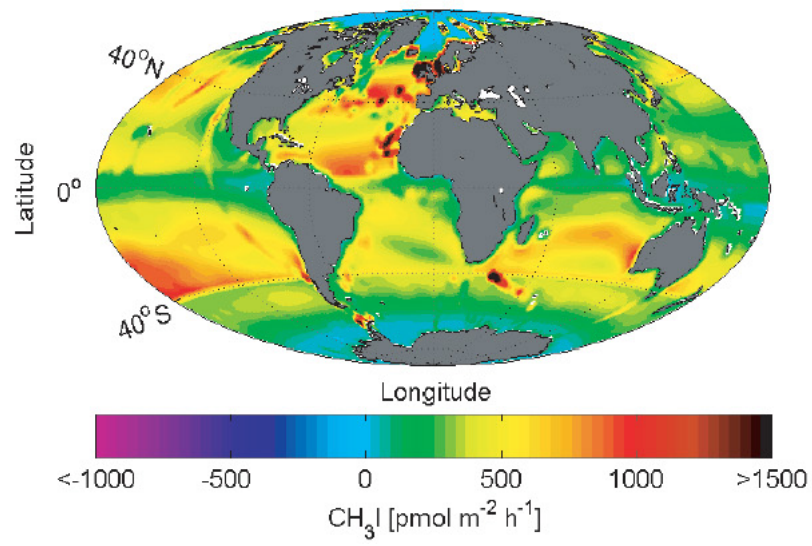

(b)
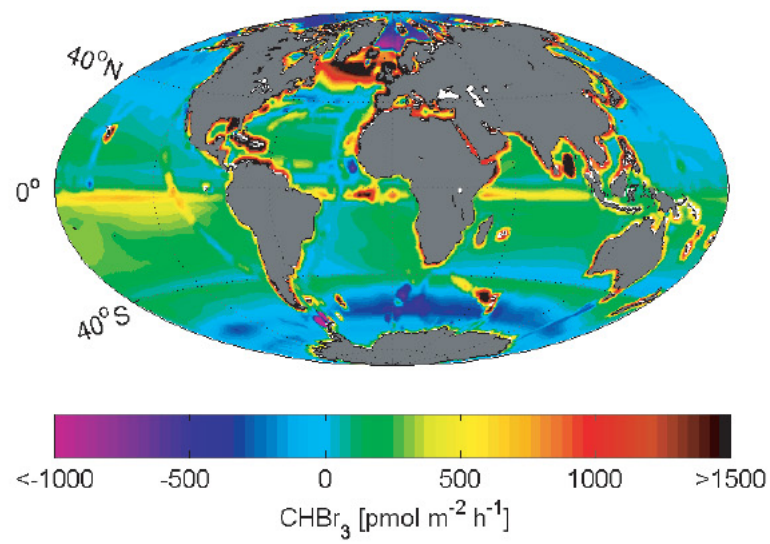

(d)

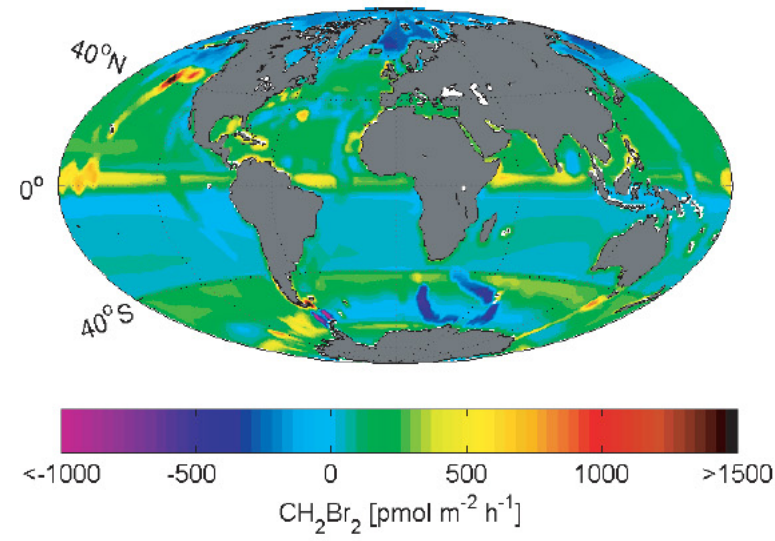

(f)

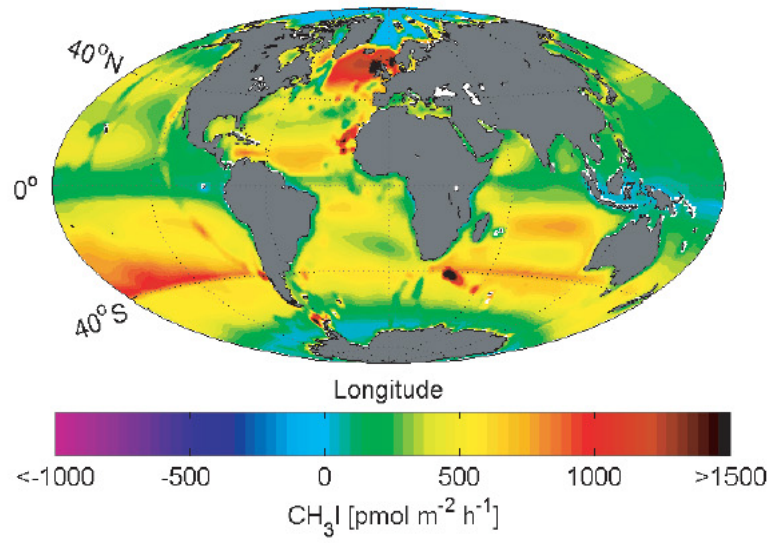

Fig. 5. Global sea-to-air flux climatology of bromoform (a, b), dibromomethane (c, d) and methyl iodide (e, f) in $\mathrm{pmol} \mathrm{m}^{-2} \mathrm{~h}^{-1} \mathrm{based}$ on the RF (a, c, e, left column) and OLS (b, d, f, right column) analyses. 
Equatorial upwelling regions, as well as the Arctic and Antarctic polar regions, are mostly in equilibrium. In comparison with $\mathrm{CHBr}_{3}$ and $\mathrm{CH}_{2} \mathrm{Br}_{2}$, the global $\mathrm{CH}_{3} \mathrm{I}$ sea-to-air fluxes are generally positive, indicating the larger supersaturations of the oceanic waters. The OLS regression shows the North Atlantic to be a very strong source region for atmospheric methyl iodide. Coast and shelf regions transport only $\sim 13 \%$ of $\mathrm{I}\left(\mathrm{CH}_{3} \mathrm{I}\right)$ to the atmosphere. The open ocean contribution of $87 \%$ is more than the estimate from Butler et al. (2007) of $50 \%$ open ocean emissions of methyl iodide. Possibly, the subtropical gyre regions are more distinctive source areas in our climatology than in Butler et al. (2007). The southern tropics and subtropics represent the regions with the highest emission strength, decreasing towards the polar areas (Table 3). We calculate a global sea-to-air flux for $\mathrm{CH}_{3} \mathrm{I}$ of $\sim 1.24 \mathrm{Gmol} \mathrm{Iyr}^{-1}(\mathrm{RF})$ and $\sim 1.45 \mathrm{Gmol} \mathrm{Iyr}^{-1}$ (OLS).

\subsection{Evaluation of RF and OLS results}

All subtropical regions, and especially the equator, show a large temporal and spatial variability in the data, which is reflected in the enhanced RMSE parameter (Tables S1 and S2 in the Supplement). The wide concentration ranges might be caused by real variations between sampling in different seasons, where the seasonally varying strength and expansion of upwelling (equatorial and coastal) (Minas et al., 1982; Hagen et al., 2001) and solar flux may cause different concentrations of the compounds.

The evaluation of the two regression methods shows that $\mathrm{RF}$ is more representative of a climatology, since it is calculating a regression independently of outliers and weighted by the data distribution. In comparison, the OLS regression weights outliers, and, hence considers extreme data and variability more than the RF method (Fig. 2). The global appearances of RF and OLS maps are not extremely different (see Supplement). Nevertheless, they introduce slight differences in the concentration gradients and in the sea-to-air flux climatologies.

The influence of the RF and the OLS regression for the global surface concentration distribution in atmosphere and ocean, which has consequences for the concentration gradient, is shown in Table 1 and Fig. 6. In general, the OLS technique calculates higher mean and median values, including the enhanced concentrations and outliers. Additionally, bromoform shows higher variance compared with the other compounds in both techniques and reflects the high data variability between coastal and open ocean bromoform concentrations. Further, the calculated concentration gradient from the OLS method exhibits stronger source (emission into the atmosphere) and weaker sink regions compared with RF, which is again most pronounced for bromoform (Fig. 6). The OLS and RF distribution (mean, median and standard deviation) for dibromomethane and methyl iodide are in closer agreement compared with bromoform. The reason for this
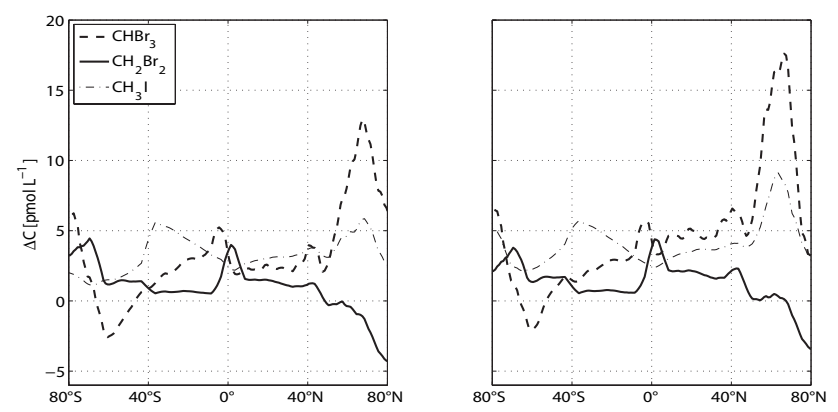

Fig. 6. Zonal mean concentration gradients for bromoform (dashed line), dibromomethane (solid line) and methyl iodide (dash-dotted line) in pmol L ${ }^{-1}$, calculated with RF (left side) and OLS (right side) methods.

smaller difference between RF and OLS is the occurrence of less extreme values in the concentration gradients for $\mathrm{CH}_{2} \mathrm{Br}_{2}$ and $\mathrm{CH}_{3} \mathrm{I}$ compared with $\mathrm{CHBr}_{3}$. The global surface emissions of bromoform, dibromomethane and methyl iodide yield a similar spatial distribution with both techniques (Table 2).

\subsection{Comparison of estimation methods}

In the following section we compare our emission climatology with recently published estimates, including different calculation techniques (i.e. bottom-up and top-down approaches), as well as laboratory experiments (Table 6). The global bromoform emission estimates show the largest difference between the studies.

Warwick et al. (2006) modelled surface mixing ratios using different emission scenarios and fitted them to the available atmospheric measurements. These scenarios applied different global emission estimates, e.g. the bottom-up estimate from Quack and Wallace (2003). The course resolution of $2.8^{\circ} \times 2.8^{\circ}$ used in the Warwick study does not well resolve the coastal areas, which are thought to be the main source for bromoform. In addition the applied uniform interpolations do not reflect the actual conditions. In the results of Warwick et al. (2006), the coastlines further north and south of the tropics exhibit no enhanced atmospheric bromoform concentrations or emission to the atmosphere compared to the open ocean. This does not reflect the in situ measurements from the HalOcAt database. Based on local bromoform measurements in Southeast Asia, Pyle et al. (2011) reduced the emission estimate of Warwick et al. (2006) in this coastal area. This study shows the importance of local measurements for the improvement of global estimates. Other model studies based on the ideas of Warwick et al. (2006), e.g. Kerkweg et al. (2008), show the same underestimation of coastal emissions in the extra tropics. In contrast, Liang et al. (2010) consider all coastlines with enhanced emissions in their scenario; furthermore the finer classification of their emission scenario compared with Warwick et al. (2006) is 
Table 1. Statistical moments: mean $(\mu)$, median, standard deviation $(\sigma)$, minimum and maximum values of atmospheric mixing ratio (ppt) and oceanic concentration ( $\mathrm{pmol} \mathrm{L}{ }^{-1}$ ) climatologies of $\mathrm{CHBr}_{3}, \mathrm{CH}_{2} \mathrm{Br}_{2}$ and $\mathrm{CH}_{3} \mathrm{I}$ based on the RF and OLS regression analyses.

\begin{tabular}{|c|c|c|c|c|c|c|c|c|c|c|}
\hline \multirow[t]{2}{*}{ Compound } & \multicolumn{2}{|c|}{$\mu$} & \multicolumn{2}{|c|}{ Median } & \multicolumn{2}{|c|}{$\sigma$} & \multicolumn{2}{|c|}{ Minimum } & \multicolumn{2}{|c|}{ Maximum } \\
\hline & $\mathrm{RF}$ & OLS & $\mathrm{RF}$ & OLS & $\mathrm{RF}$ & OLS & $\mathrm{RF}$ & OLS & $\mathrm{RF}$ & OLS \\
\hline \multicolumn{11}{|l|}{ Atmosphere } \\
\hline $\mathrm{CHBr}_{3}$ & 0.9 & 1.1 & 1.0 & 1.6 & 1.2 & 1.6 & 0.01 & 0.03 & 53.1 & 53.1 \\
\hline $\mathrm{CH}_{2} \mathrm{Br}_{2}$ & 1.0 & 1.1 & 1.0 & 1.1 & 0.4 & 0.4 & 0.07 & 0.07 & 7.8 & 7.8 \\
\hline $\mathrm{CH}_{3} \mathrm{I}$ & 0.7 & 0.8 & 0.7 & 0.7 & 0.4 & 0.4 & 0.05 & 0.01 & 7.3 & 7.3 \\
\hline \multicolumn{11}{|l|}{ Ocean } \\
\hline $\mathrm{CHBr}_{3}$ & 5.9 & 9.3 & 3.1 & 4.4 & 9.8 & 14.6 & 0.29 & 0.19 & 823.0 & 823.0 \\
\hline $\mathrm{CH}_{2} \mathrm{Br}_{2}$ & 2.9 & 3.5 & 1.9 & 2.6 & 2.4 & 2.7 & 0.01 & 0.01 & 89.8 & 89.8 \\
\hline $\mathrm{CH}_{3} \mathrm{I}$ & 3.2 & 3.9 & 2.6 & 3.4 & 2.6 & 2.9 & 0.03 & 0.05 & 39.6 & 39.6 \\
\hline
\end{tabular}

Table 2. Statistical moments: mean $(\mu)$, median, standard deviation $(\sigma)$, minimum and maximum values for the calculated global sea-to-air flux climatologies of $\mathrm{CHBr}_{3}, \mathrm{CH}_{2} \mathrm{Br}_{2}$ and $\mathrm{CH}_{3} \mathrm{I}$ based on the RF and OLS regression analyses, in $\mathrm{pmol} \mathrm{m}^{-2} \mathrm{~h}^{-1}$.

\begin{tabular}{|c|c|c|c|c|c|c|c|c|c|c|}
\hline \multirow{2}{*}{$\begin{array}{l}\text { Global Sea-to-Air } \\
\text { Flux Climatology }\end{array}$} & \multicolumn{2}{|c|}{$\mu$} & \multicolumn{2}{|c|}{ Median } & \multicolumn{2}{|c|}{$\sigma$} & \multicolumn{2}{|c|}{ Minimum } & \multicolumn{2}{|c|}{ Maximum } \\
\hline & $\mathrm{RF}$ & OLS & $\mathrm{RF}$ & OLS & $\mathrm{RF}$ & OLS & $\mathrm{RF}$ & OLS & $\mathrm{RF}$ & OLS \\
\hline $\mathrm{CHBr}_{3}$ & 154.9 & 236.2 & 47.1 & 89.7 & 549.7 & 749.6 & -5339 & -5230 & 19618 & 19618 \\
\hline $\mathrm{CH}_{2} \mathrm{Br}_{2}$ & 76.5 & 112.4 & 79.3 & 78.8 & 237.9 & 258.4 & -1687 & -1714 & 3978 & 3978 \\
\hline $\mathrm{CH}_{3} \mathrm{I}$ & 329.6 & 405.0 & 307.3 & 385.2 & 289.8 & 348.3 & -49 & -55 & 4895 & 4878 \\
\hline
\end{tabular}

Table 3. The emission distribution of $\mathrm{CHBr}_{3}, \mathrm{CH}_{2} \mathrm{Br}_{2}$ and $\mathrm{CH}_{3} \mathrm{I}$ calculated with two different regression methods (RF and OLS) for different latitudinal bands (see text for explanation), expressed as a percentage.

\begin{tabular}{|c|c|c|c|c|c|c|}
\hline & \multicolumn{2}{|c|}{$\mathrm{CHBr}_{3}$} & \multicolumn{2}{|c|}{$\mathrm{CH}_{2} \mathrm{Br}_{2}$} & \multicolumn{2}{|c|}{$\mathrm{CH}_{3} \mathrm{I}$} \\
\hline & RF & OLS & $\mathrm{RF}$ & OLS & $\mathrm{RF}$ & OLS \\
\hline $50-90^{\circ} \mathrm{N}$ & 22.8 & 21.2 & -9.7 & -4.9 & 10.4 & 7.6 \\
\hline $20-50^{\circ} \mathrm{N}$ & 7.4 & 15.9 & 13.7 & 19.1 & 19.8 & 20.3 \\
\hline $20^{\circ} \mathrm{N}-20^{\circ} \mathrm{S}$ & 54.7 & 43.6 & 48.9 & 44.3 & 28.9 & 32.1 \\
\hline $20-50^{\circ} \mathrm{S}$ & 22.7 & 19.3 & 25.1 & 22.1 & 32.8 & 34.1 \\
\hline $50-90^{\circ} \mathrm{S}$ & -7.6 & 0.007 & 22.0 & 19.5 & 8.2 & 5.9 \\
\hline
\end{tabular}

similar to our study. Another comparable classification (latitudinal bands, higher emissions in coastal regions) is used in the model (top-down approach) by Ordonez et al. (2012), who parameterized oceanic polybromomethanes emissions based on a chlorophyll $a$ (chl $a$ ) dependent source in the tropical ocean $\left(20^{\circ} \mathrm{N}\right.$ to $\left.20^{\circ} \mathrm{S}\right)$. We also see the occurrence of enhanced bromoform, as well as dibromomethane emissions in tropical upwelling regions and in coastal regions, although a direct correlation between chl $a$ and the VSLS compounds is not apparent from the observations (Abrahamsson et al., 2004; Quack et al., 2007b). Palmer and Reason (2009) developed a parameterization for $\mathrm{CHBr}_{3}$ based on chl $a$ (between $30^{\circ} \mathrm{N}$ and $30^{\circ} \mathrm{S}$ ), including other parameters (mixed layer depth, sea surface temperature and salinity, wind speed). The correlation between his modelled values and observations is, with $r^{2}=0.4$, low, which reveals the deficiency of this method (and chl $a$ ).

In some studies local emission estimates are extrapolated to a global scale. Extrapolating near-shore emissions may significantly overestimate the global sea-to-air fluxes, since they generally include elevated coastal concentrations, which are not representative of the global ocean. Yokouchi et al. (2005) applied a coastal emission ratio of $\mathrm{CHBr}_{3} / \mathrm{CH}_{2} \mathrm{Br}_{2}$ of 9 , and a global emission of $0.76 \mathrm{Gmol} \mathrm{Br} \mathrm{yr}^{-1}$ for $\mathrm{CH}_{2} \mathrm{Br}_{2}$ to infer a global $\mathrm{CHBr}_{3}$ flux estimate of $10.26 \pm 3.88 \mathrm{Gmol} \mathrm{Br} \mathrm{yr}^{-1}$. O'Brien et al. (2009) followed the same method and extrapolated local near-shore measurements in the region surrounding Cape Verde to a global scale using an emission ratio of $\mathrm{CHBr}_{3} / \mathrm{CH}_{2} \mathrm{Br}_{2}=13$. The global fluxes from these studies are nearly four times higher than those calculated in our study. However, since the emission ratios of $\mathrm{CHBr}_{3}$ to $\mathrm{CH}_{2} \mathrm{Br}_{2}$ are generally higher in coastal regions than in the other areas (Hepach et al., 2013), the calculated global flux for $\mathrm{CHBr}_{3}$ could be an overestimation.

Butler et al. (2007) and Quack and Wallace (2003) interpolated oceanic and atmospheric in situ measurements for global emission estimates. Butler et al. (2007) subdivided the ocean into the main basins and calculated the fraction of each compound for each region as a percentage. Coastal areas were not considered. The extrapolation by Quack and Wallace (2003) contained most of the currently available 
Table 4. Fluxes of bromine from $\mathrm{CHBr}_{3}$ and $\mathrm{CH}_{2} \mathrm{Br}_{2}$ in $\mathrm{Gmol} \mathrm{Br} \mathrm{yr}^{-1}$, and iodine from $\mathrm{CH}_{3} \mathrm{I}$ in $\mathrm{Gmol} \mathrm{Iyr}^{-1}$.

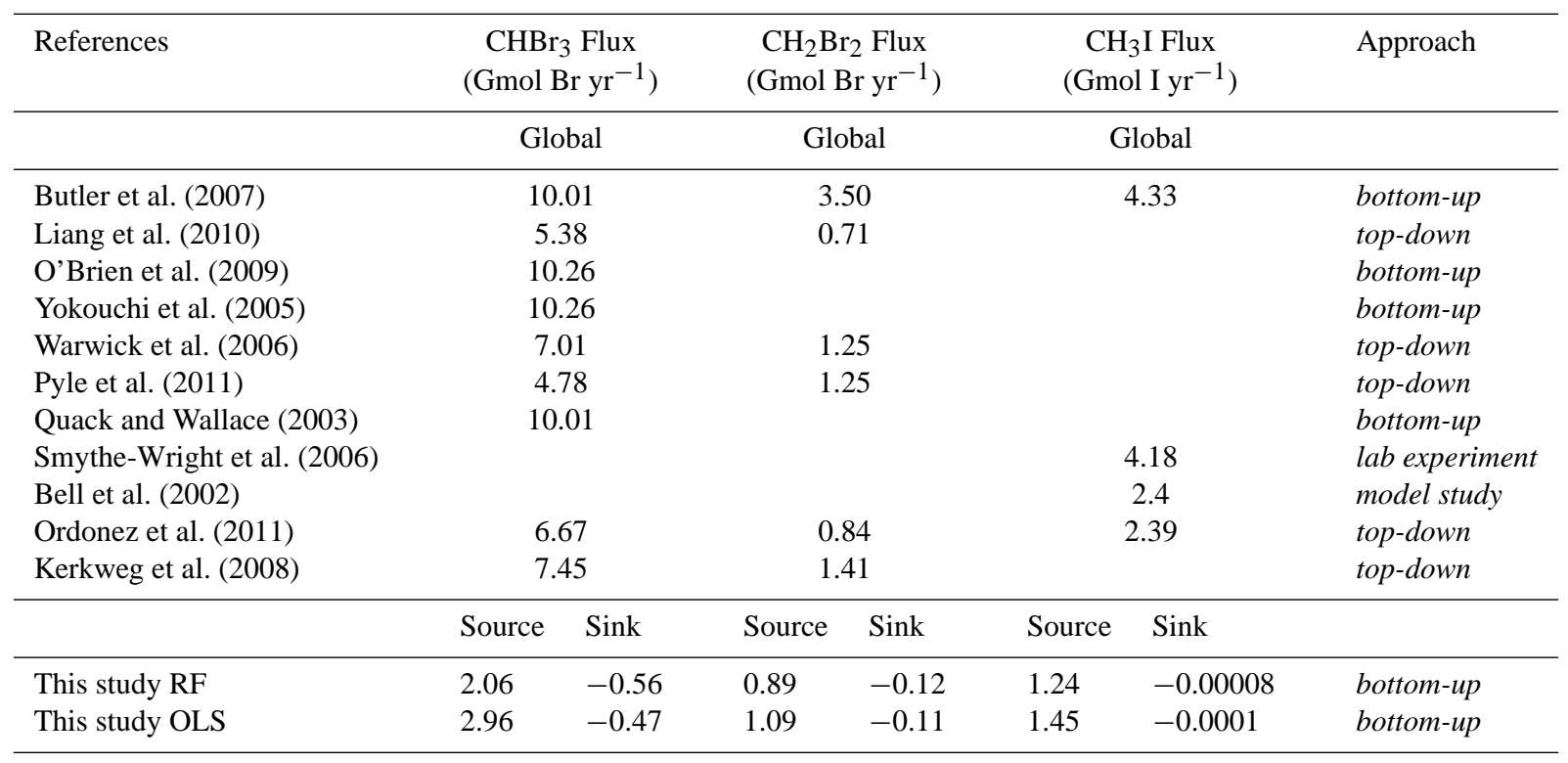

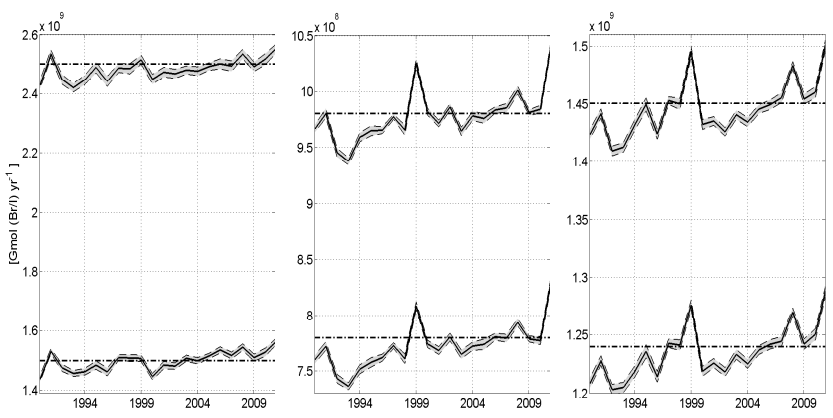

Fig. 7. Inter-annual sea-to-air flux variability over 1989-2011 (bold solid line) of bromoform (left), dibromomethane (centre) and methyl iodide (right) calculated with the two regression techniques (RF (lower panels) and OLS (upper panels)), in $\mathrm{Gmol}(\mathrm{Br} / \mathrm{I}) \mathrm{yr}^{-1}$. Additionally, the respective climatological value is marked (dashdotted line) as well as the standard deviation (grey shaded).

published measurements and used a finer area classification for shore, shelf and open ocean regions as well as for latitudinal bands. Both bottom-up approaches applied a coarse data interpolation compared to the classification and regression techniques used in this study and appear too high.

We calculate a global $\mathrm{CH}_{2} \mathrm{Br}_{2}$ sea-to-air flux of $0.77-$ $0.98 \mathrm{Gmol} \mathrm{Bryr}^{-1}$, which is also in the lower (0.71$3.5 \mathrm{Gmol} \mathrm{Br} \mathrm{yr}^{-1}$ ) range of the other estimates (Table 4), but is in much closer agreement compared to the other compounds. Reasons for the good agreement with recent studies could be the longer atmospheric lifetime of $\mathrm{CH}_{2} \mathrm{Br}_{2}$ and the lower variance of sea water values which cause a more homogenous global distribution.
Some earlier emission estimations for $\mathrm{CH}_{3} \mathrm{I}$ (1.05$10.5 \mathrm{Gmol} \mathrm{Iyr}^{-1}$ ) are given by Bell et al. (2002), who produced the first seasonal model simulation of global oceanic and atmospheric $\mathrm{CH}_{3} \mathrm{I}$ surface concentrations. A low correlation between observations and modelled data was obtained $(r=0.4)$. The authors assumed a missing biological sink of $\mathrm{CH}_{3} \mathrm{I}$ in the ocean that would have reduced their computed concentrations to better match the observations. Sink and source mechanisms for the formation of $\mathrm{CH}_{3} \mathrm{I}$ are not fully understood, making it difficult to model $\mathrm{CH}_{3} \mathrm{I}$ emissions based on source and sink parameterizations. In our study a global sea-to-air flux of $1.24-1.45 \mathrm{Gmol} \mathrm{I} \mathrm{yr}^{-1}$ is estimated, which is within the lower range of earlier studies (Table 4). Our calculated climatology uses a larger dataset than the study of Bell et al. (2002). Ordonez et al. (2012) calculate a global $\mathrm{CH}_{3} \mathrm{I}$ flux of the same magnitude as our study using a top-down approach with a modified global chemistry model that includes bromine and iodine chemistry. SmytheWright et al. (2006) calculated a global flux of iodine from Prochlorococcus marinus of $\sim 4.18 \mathrm{Gmol} \mathrm{Iyr}^{-1}$ based on measurements from two cruises. The latter study assumes that this phytoplankton species is the major marine source of atmospheric $\mathrm{CH}_{3} \mathrm{I}$. The assumption of Smythe-Wright et al. (2006) that the oceanic surface $\left(<40^{\circ} \mathrm{N}\right.$ and $\left.\mathrm{S}\right)$ is covered with $\mathrm{CH}_{3} \mathrm{I}$-producing picoplankton might overestimate the global $\mathrm{CH}_{3} \mathrm{I}$ sea-to-air flux. Calculations based on culture experiments from Brownell et al. (2010) demonstrate that Prochlorococcus marinus accounts only for $0.03 \%$ of the global $\mathrm{CH}_{3} \mathrm{I}$ budget and is not a globally significant source of $\mathrm{CH}_{3}$ I. Hughes et al. (2011) suggest different culture conditions as a possible explanation for the contradictory findings of the culture experiments. The bottle experiments of 

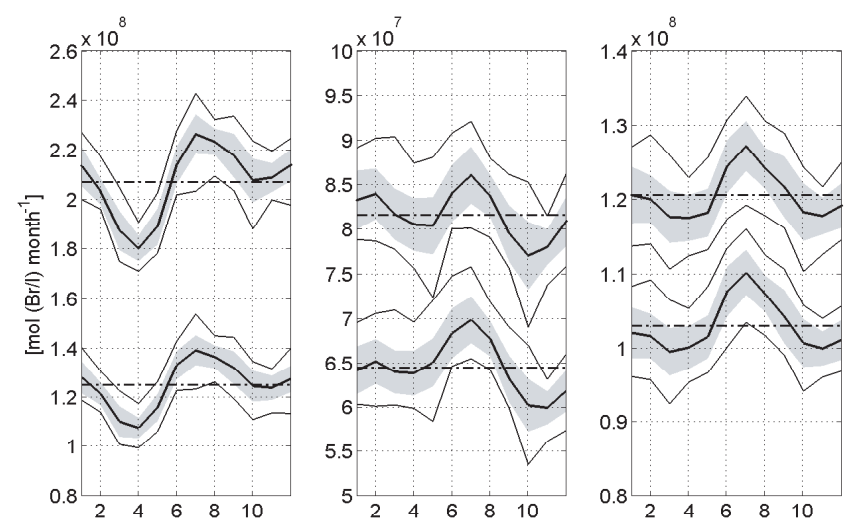

Fig. 8. Global monthly sea-to-air flux averages of bromoform (left), dibromomethane (centre) and methyl iodide (right) in mol $(\mathrm{Br} / \mathrm{I})$ month ${ }^{-1}$ (bold solid line) from 1989 to 2011, including their standard deviation (grey shaded area) and their minimum and maximum value (solid line). Additionally, the respective annual mean value is marked (dash-dotted line). The upper graphs show the oceanic emissions using the OLS regression technique and the bottom graphs the RF calculated fluxes.

Richter and Wallace (2004) suggested a photochemical production pathway of $\mathrm{CH}_{3} \mathrm{I}$ in open ocean water which might also explain our surface distribution (enhanced emissions in the subtropical gyre regions).

The comparison of our global sea-to-air fluxes with other global estimates reveals the greatest discrepancy for bromoform. We have shown that bromoform levels are the most variable in the ocean and atmosphere. Possibly, the underrepresentation of extreme values generates too small concentration gradients, which reduces our total emission estimate. Especially in coastal and shelf regions, the $1^{\circ} \times 1^{\circ}$ grid resolution cannot resolve these extreme concentrations and very likely leads to underestimated emissions.

\section{Variability of the climatological sea-to-air fluxes}

We calculate global emission fields using fixed oceanic concentrations and atmospheric mixing ratios and the highest available temporal resolution of the input parameters over the time period 1989-2011: 6-hourly means of $U$, SST, SLP and monthly means for the SSS. The global emissions of every time step are averaged over each month and the average monthly emissions are summed to the annual climatological emission. The climatologies thus include annual, seasonal and short timescale temporal variability.

\subsection{Variability of the concentration data}

The calculated global $1^{\circ} \times 1^{\circ}$ maps of oceanic concentrations and atmospheric mixing ratios include in situ measurements from 1989 to 2011, illustrating a climatological year and covering the entire globe. Seasonally changing condi- tions, e.g. light and water temperature or biological species composition, which have an influence on the variability of the air and water concentrations in certain areas (Archer et al., 2007; Orlikowska and Schulz-Bull, 2009), are not considered because of the generally poor temporal data coverage. Fitting the in situ measurements onto our $1^{\circ} \times 1^{\circ}$ grid (by using objective mapping) leads on average to a reduction of the initial atmospheric mixing ratios and oceanic concentrations of less than $1 \%$. The accuracy of the interpolation is limited by the sparse data coverage and the regression technique used. Seasonal and spatial accuracy could be improved if a larger dataset was available. Thus we recommend more measurements, especially in the ocean, as well as a refinement of process understanding. The temporal variability of the SST is considered in the concentration gradient, used in the sea-to-air flux calculation, by computing a new equilibrium concentration for every $6 \mathrm{~h}$ time step from 1989 to 2011.

\subsection{Annual and seasonal variability}

The inter-annual variability of the global sea-to-air flux from 1989 to 2011 is small and generally less than $5 \%$ (Fig. 7). The halocarbons all show a positive trend towards 2011 . Within a year, the global flux varies monthly for every halogenated compound (Fig. 8). The maximum global sea-to-air flux is most pronounced in July for all compounds, while the minimum is reached in March-April for $\mathrm{CHBr}_{3}$ and $\mathrm{CH}_{3} \mathrm{I}$ and in October for $\mathrm{CH}_{2} \mathrm{Br}_{2}$. The climatological monthly flux and the corresponding minimum and maximum monthly fluxes vary between 9 and $21 \%$. $\mathrm{CH}_{3} \mathrm{I}$ shows the smallest mean deviation with 9 and $11 \%$ for OLS and RF respectively, whereas the variation for $\mathrm{CH}_{2} \mathrm{Br}_{2}$ is between 14 and $17 \%$ and for $\mathrm{CHBr}_{3}$ between 17 and $21 \%$. Thus the seasonal variation of the global climatological flux is larger than the inter-annual variation, despite the shifting of the seasons (half a year) between the Northern Hemisphere and Southern Hemisphere. The global climatological fluxes, obtained from the sum of the monthly averages between 1989 and 2011, describe the current best possible estimates of the moderately varying annual and seasonal global emissions. However, the results do not consider a seasonally varying influence of either the water or the air concentration on the emission because the current sparse investigations do not allow a suitable parameterization of the VSLS yet.

\subsection{Short time variability of fluxes}

In situ fluxes from a cruise (TransBrom) between Japan and Australia in October 2009 are compared to the nearest grid points of our climatology (Fig. 9) as an example for the influence of short time variability. The TransBrom data include $105 \mathrm{CHBr}_{3}$ and $\mathrm{CH}_{2} \mathrm{Br}_{2}$ measurements and $96 \mathrm{CH}_{3} \mathrm{I}$ measurements, and are included in the climatology. The cruise transited through different biogeochemical regions with varying meteorological conditions influencing 

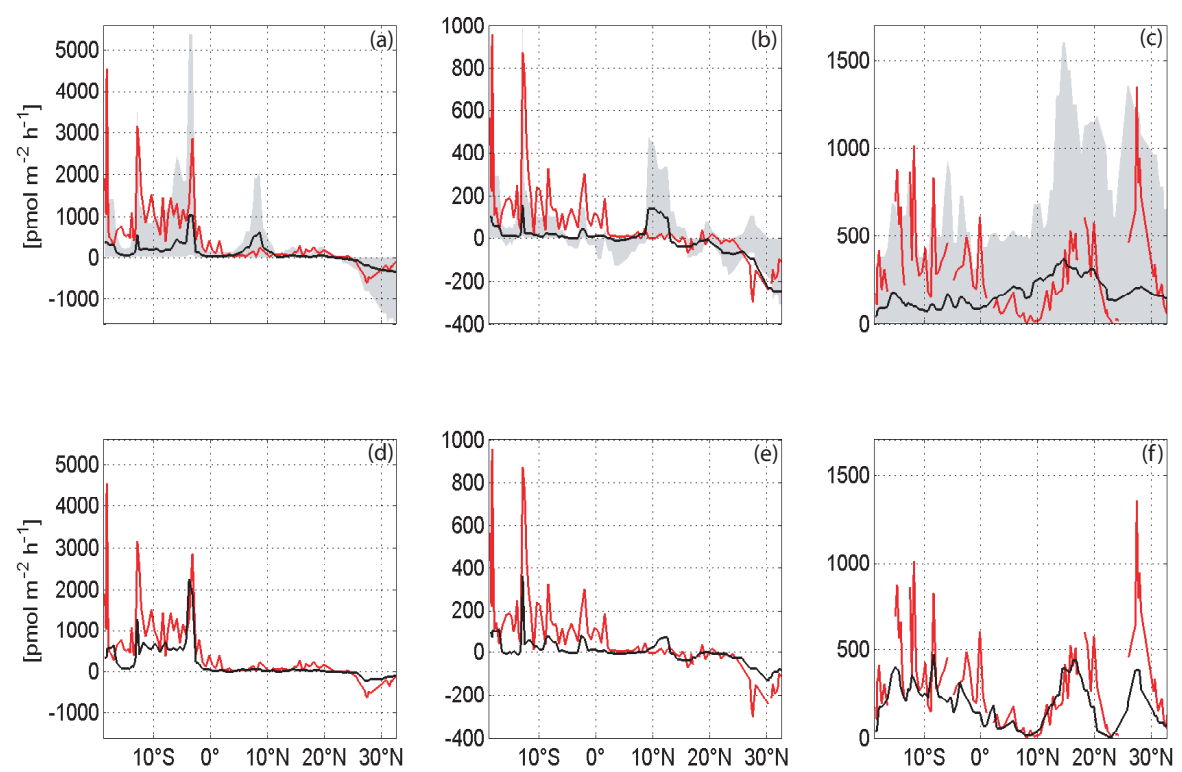

Fig. 9. The upper panels illustrate the comparison between our climatological estimate (black line) and the in situ sea-to-air fluxes from the TransBrom cruise (red line) for bromoform (a), dibromomethane (b) and methyl iodide (c) in pmol m $\mathrm{m}^{-2} \mathrm{~h}^{-1}$ (see more details in the text) including the climatological minimum and maximum values (grey shaded area). The lower panels represent the same in situ measurements compared to our model values using the nearest 6-hourly mean of SST, $U$ and SLP and monthly mean of SSS with fixed mixing ratios and oceanic concentrations calculated with the RF method for bromoform (d), dibromomethane (e) and methyl iodide (f) (the emissions using OLS look similar).

the strength of VSLS emissions (Krüger and Quack, 2012). The in situ and climatological sea-to-air fluxes for bromoform and dibromomethane compare very well in the Northern Hemisphere, where small concentration gradients are found in the open oceans. The enhanced emissions in the Southern Hemisphere encountered during the cruise are under-represented in the climatology. Comparison of the methyl iodide in situ fluxes and the climatology shows a similar trend, although the extreme values of the in situ measurements are highly under-represented in the climatological mean flux value. Our climatology underestimates the shortterm measured fluxes by smoothing the values of the varying input parameters. The mean deviation between the climatology and the in situ fluxes during October 2009 is $\sim 120 \%$ for $\mathrm{CHBr}_{3}, \sim 20 \%$ for $\mathrm{CH}_{2} \mathrm{Br}_{2}$ and $\sim 176 \%$ for $\mathrm{CH}_{3} \mathrm{I}$, respectively.

We also calculate the sea-to-air fluxes using the nearest temporal and spatial 6-hourly means (highest available resolution) of SST, SLP and $U$, the monthly mean of the SSS and the climatological oceanic concentration and mixing ratios, and compare them to the measured fluxes (Fig. 9). The mean deviation between the 6-hourly means and the in situ fluxes for the three compounds is only $\sim 48 \%$ for $\mathrm{CHBr}_{3}, \sim 15 \%$ for $\mathrm{CH}_{2} \mathrm{Br}_{2}$ and $51 \%$ for $\mathrm{CH}_{3} \mathrm{I}$. These values show the good match between "modelled" and in situ measurements and validate the predictive capability of this approach. The climatological minimum and maximum values of the cruise nearest data points (Fig. 9, upper panel) reveal how variable the "modelled" fluxes can be at a single location. While most in situ fluxes are included in the $6 \mathrm{~h}$ minimum and maximum range from 1989 to 2011, it is also noteworthy that even with this high temporal $(6 \mathrm{~h})$ resolution of input parameters, the "modelled" fluxes can neither match the extreme values of the encountered in situ fluxes, nor do they resolve the high variability of the in situ fluxes completely. An additional factor for the under-representation of the extreme in situ values is the mean concentration gradient $\left(1^{\circ} \times 1^{\circ}\right.$ resolution $)$ in our "model". In the vicinity of source regions, e.g. coast lines, the water concentrations can vary by more than $100 \%$ over short distances (Butler et al., 2006), which strongly influences the in situ fluxes and is likely not resolved in the model due to poor data coverage.

\section{Summary and conclusion}

Global sea-to-air flux climatologies (considering the time span from 1989 to 2011 of the three important short-lived halocarbons, bromoform, dibromomethane and methyl iodide) are calculated based on surface oceanic and atmospheric measurements from the HalOcAt database. The physical and biogeochemical factors of the compounds' distributions in ocean and atmosphere are also considered. Data are classified into coastal, shelf and open ocean regions, and are interpolated on a $1^{\circ} \times 1^{\circ}$ grid. The missing grid values are 
filled with robust fit (RF) and ordinary least squares (OLS) regression techniques based on the latitudinal and longitudinal distribution of the compounds. The RF interpolation estimates background values, since it is weighted on the quantity of measurements, whereas the OLS regressions include extreme data and therefore represent our highest values. Global emission fields are calculated with a high temporal resolution of 6-hourly wind speed, sea surface temperature and sea level pressure data. The climatological annual global flux for 1989 to 2011 is obtained as sum of the monthly average fluxes. We estimate positive global sea-to-air fluxes of $\mathrm{CHBr}_{3}$, $\mathrm{CH}_{2} \mathrm{Br}_{2}$ and $\mathrm{CH}_{3} \mathrm{I}$ of $2.06 / 2.96,0.89 / 1.09 \mathrm{Gmol} \mathrm{Br} \mathrm{yr}^{-1}$ and $1.24 / 1.45 \mathrm{Gmol} \mathrm{Iyr}^{-1}$, based on RF/OLS respectively, which are all at the lower end of earlier studies. Previous global climatological estimate studies have not determined negative fluxes (flux into the ocean). We estimate negative global seato-air fluxes of $-0.47 /-0.56,-0.11 /-0.12 \mathrm{Gmol} \mathrm{Br} \mathrm{yr}^{-1}$ and $-0.08 /-0.1 \mathrm{Mmol} \mathrm{I} \mathrm{yr}^{-1}$ for $\mathrm{CHBr}_{3}, \mathrm{CH}_{2} \mathrm{Br}_{2}$ and $\mathrm{CH}_{3} \mathrm{I}$, respectively. The net oceanic emissions of our climatology are 1.5/2.5 $\mathrm{Gmol} \mathrm{Br} \mathrm{yr}^{-1}$ for $\mathrm{CHBr}_{3}, 0.78 / 0.98 \mathrm{Gmol} \mathrm{Br} \mathrm{yr}^{-1}$ for $\mathrm{CH}_{2} \mathrm{Br}_{2}$, and $1.24 / 1.45 \mathrm{Gmol} \mathrm{I} \mathrm{yr}^{-1}$ for $\mathrm{CH}_{3} \mathrm{I}$.

Our low bottom-up emission estimates, compared to recent top-down approaches, especially for bromoform, are most likely caused by an under-representation of extreme emissions. Observed high temporal and spatial in situ variances cannot be resolved in the $1^{\circ} \times 1^{\circ}$ grid climatology. It is still unclear how important extreme events are for the global bromoform budget, but we suggest that small spatial and temporal events of high oceanic bromoform emissions are important for the transport of bromine into the troposphere and lower stratosphere. The monthly variation of the global climatological flux (9-21\%) is contained within our calculations and it is larger than the inter-annual variability, which is generally less than $5 \%$ for all three compounds.

Our global sea-to-air flux estimates can be used as input for different model calculations. The existing uncertainties can be reduced by enlarging of the HalOcAt database with more measurements, especially in ocean waters, common calibration techniques and more basic research into the underlying source and sink processes.

\section{Supplementary material related to this article is available online at: http://www.atmos-chem-phys.net/13/ 8915/2013/acp-13-8915-2013-supplement.zip.}

Acknowledgements. We thank all contributors sending their data to the HalOcAt database and for their helpful comments on the manuscript. We also thank our assisting student helpers Julian Kinzel, Christian Müller, Eike Hümpel, Anja Müller and Theresa Conradi who populated the database, which started in 2009. This work was financially supported by the WGL project TransBrom, the European commission under the project SHIVA (grant no. 226 224) and by the German Federal Ministry of Education and Research (BMBF) during the project SOPRAN (grant no: 03F0611A). SOLAS Integration (Surface Ocean Lower Atmosphere Study; http://www.bodc.ac.uk/solas_integration/) helped instigate this project and Tom Bell and Peter Liss were supported in this by a NERC UK SOLAS Knowledge Transfer grant (NE/E001696/1). Part of this project was supported by COST (European Cooperation in Science and Technology) Action 735, a European Science Foundation-supported initiative. Additionally, we would like to thank the ECMWF for providing the ERA Interim reanalysis data. We thank two anonymous reviewers for their useful comments and advice.

The service charges for this open access publication have been covered by a Research Centre of the Helmholtz Association.

Edited by: R. Volkamer

\section{References}

Abrahamsson, K., Bertilsson, S., Chierici, M., Fransson, A., Froneman, P. W., Loren, A., and Pakhomov, E. A.: Variations of biochemical parameters along a transect in the southern ocean, with special emphasis on volatile halogenated organic compounds, Deep-Sea Res. Part II, 51, 2745-2756, doi:10.1016/j.dsr2.2004.09.004, 2004.

Amachi, S., Kamagata, Y., Kanagawa, T., and Muramatsu, Y.: Bacteria mediate methylation of iodine in marine and terrestrial environments, Appl. Environ. Microbiol., 67, 2718-2722, doi:10.1128/aem.67.6.2718-2722.2001, 2001.

Antonov, J. I., Seidov, D., Boyer, T. P., Locarnini, R. A., Mishonov, A. V., Garcia, H. E., Baranova, O. K., Zweng, M. M., and Johnson, D. R.: World ocean atlas 2009, Volume 2: Salinity. S. Levitus Ed. NOAA Atlas NESDIS 69, U.S. Government Printing Office, Washington, DC, 184 pp., 2010.

Archer, S. D., Goldson, L. E., Liddicoat, M. I., Cummings, D. G., and Nightingale, P. D.: Marked seasonality in the concentrations and sea-to-air flux of volatile iodocarbon compounds in the western English Channel, J. Geophys. Res.-Oceans, 112, C08009, doi:10.1029/2006jc003963, 2007.

Aschmann, J., Sinnhuber, B.-M., Atlas, E. L., and Schauffler, S. M.: Modeling the transport of very short-lived substances into the tropical upper troposphere and lower stratosphere, Atmos. Chem. Phys., 9, 9237-9247, doi:10.5194/acp-9-9237-2009, 2009.

Bates, N. R. and Merlivat, L.: The influence of short-term wind variability on air-sea $\mathrm{CO}_{2}$ exchange, Geophys. Res. Lett., 28, 32813284, doi:10.1029/2001gl012897, 2001.

Bell, N., Hsu, L., Jacob, D. J., Schultz, M. G., Blake, D. R., Butler, J. H., King, D. B., Lobert, J. M., and Maier-Reimer, E.: Methyl iodide: Atmospheric budget and use as a tracer of marine convection in global models, J. Geophys. Res.-Atmos., 107, 4340, doi:10.1029/2001jd001151, 2002.

Bondu, S., Cocquempot, B., Deslandes, E., and Morin, P.: Effects of salt and light stress on the release of volatile halogenated organic compounds by Solieria Chordalis: A laboratory incubation study, Bot. Mar., 51, 485-492, doi:10.1515/bot.2008.056, 2008.

Brinckmann, S., Engel, A., Bönisch, H., Quack, B., and Atlas, E.: Short-lived brominated hydrocarbons - observations in the 
source regions and the tropical tropopause layer, Atmos. Chem. Phys., 12, 1213-1228, doi:10.5194/acp-12-1213-2012, 2012.

Brownell, D. K., Moore, R. M., and Cullen, J. J.: Production of methyl halides by Prochlorococcus and Synechococcus, Glob. Biogeochem. Cy., 24, Gb2002, doi:10.1029/2009gb003671, 2010.

Butler, J. H., King, D. B., Lobert, J. M., Montzka, S. A., YvonLewis, S. A., Hall, B. D., Warwick, N. J., Mondeel, D. J., Aydin, M., and Elkins, J. W.: Oceanic distributions and emissions of short-lived halocarbons, Glob. Biogeochem. Cy., 21, Gb1023, doi:10.1029/2006gb002732, 2007.

Butler, J. H., Bell, T. G., Hall, B. D., Quack, B., Carpenter, L. J., and Williams, J.: Technical Note: Ensuring consistent, global measurements of very short-lived halocarbon gases in the ocean and atmosphere, Atmos. Chem. Phys., 10, 327-330, doi:10.5194/acp-10-327-2010, 2010.

Carpenter, L. J.: Iodine in the marine boundary layer, Chem. Rev., 103, 4953-4962, doi:10.1021/cr0206465, 2003.

Carpenter, L. J. and Liss, P. S.: On temperate sources of bromoform and other reactive organic bromine gases, J. Geophys. Res.Atmos., 105, 20539-20547, doi:10.1029/2000jd900242, 2000.

Chapman, E. G., Shaw, W. J., Easter, R. C., Bian, X., and Ghan, S. $\mathrm{J}$. : Influence of wind speed averaging on estimates of dimethylsulfide emission fluxes, J. Geophys. Res.-Atmos., 107, 4672, doi:10.1029/2001jd001564, 2002.

Chipperfield, M. P. and Pyle, J. A.: Model sensitivity studies of arctic ozone depletion, J. Geophys. Res.-Atmos., 103, 2838928403, doi:10.1029/98jd01960, 1998.

Daley, R.: Atmospheric data analysis, Cambridge University Press, Cambridge, England, 457 pp., 1991.

Dee, D. P., Uppala, S. M., Simmons, A. J., Berrisford, P., Poli, P., Kobayashi, S., Andrae, U., Balmaseda, M. A., Balsamo, G., Bauer, P., Bechtold, P., Beljaars, A. C. M., van de Berg, L., Bidlot, J., Bormann, N., Delsol, C., Dragani, R., Fuentes, M., Geer, A. J., Haimberger, L., Healy, S. B., Hersbach, H., Hólm, E. V., Isaksen, L., Kållberg, P., Köhler, M., Matricardi, M., McNally, A. P., Monge-Sanz, B. M., Morcrette, J.-J., Park, B.-K., Peubey, C., de Rosnay, P., Tavolato, C., Thépaut, J.-N., and Vitart, F.: The era-interim reanalysis: Configuration and performance of the data assimilation system, Q. J. Roy. Meteorol. Soc., 137, 553597, doi:10.1002/qj.828, 2011.

Dorf, M., Butz, A., Camy-Peyret, C., Chipperfield, M. P., Kritten, L., and Pfeilsticker, K.: Bromine in the tropical troposphere and stratosphere as derived from balloon-borne $\mathrm{BrO}$ observations, Atmos. Chem. Phys., 8, 7265-7271, doi:10.5194/acp-8-72652008, 2008.

Fuhlbrügge, S., Krüger, K., Quack, B., Atlas, E., Hepach, H., and Ziska, F.: Impact of the marine atmospheric boundary layer conditions on VSLS abundances in the eastern tropical and subtropical North Atlantic Ocean, Atmos. Chem. Phys., 13, 6345-6357, doi:10.5194/acp-13-6345-2013, 2013.

Gschwend, P. M., Mac Farlane, J. K., and Newman, K. A.: Volatile halogenated organic-compounds released to seawater from temperate marine macro algae, Science, 227, 1033-1035, doi:10.1126/science.227.4690.1033, 1985.

Hagen, E., Feistel, R., Agenbag, J. J., and Ohde, T.: Seasonal and interannual changes in intense Benguela upwelling (1982-1999), Oceanol. Acta., 24, 557-568, doi:10.1016/s03991784(01)01173-2, 2001.
Hamer, P. D., Marécal, V., Hossaini, R., Pirre, M., Warwick, N., Chipperfield, M., Samah, A. A., Harris, N., Robinson, A., Quack, B., Engel, A., Krüger, K., Atlas, E., Subramaniam, K., Oram, D., Leedham, E., Mills, G., Pfeilsticker, K., Sala, S., Keber, T., Bönisch, H., Peng, L. K., Nadzir, M. S. M., Lim, P. T., Mujahid, A., Anton, A., Schlager, H., Catoire, V., Krysztofiak, G., Fühlbrügge, S., Dorf, M., and Sturges, W. T.: Modelling the chemistry and transport of bromoform within a sea breeze driven convective system during the SHIVA Campaign, Atmos. Chem. Phys. Discuss., 13, 20611-20676, doi:10.5194/acpd-13-206112013, 2013.

Happell, J. D. and Wallace, D. W. R.: Methyl iodide in the Greenland/Norwegian seas and the tropical Atlantic Ocean: Evidence for photochemical production, Geophys Res. Lett., 23, 21052108, doi:10.1029/96gl01764, 1996.

Hepach, H., Quack, B., Ziska, F., Fuhlbrügge, S., Atlas, E. L., Peeken, I., Krüger, K., and Wallace, D. W. R.: Drivers of diel and regional variations of halocarbon emissions from the tropical North East Atlantic, Atmos. Chem. Phys. Discuss., 13, 1970119750, doi:10.5194/acpd-13-19701-2013, 2013.

Hossaini, R., Mantle, H., Chipperfield, M. P., Montzka, S. A., Hamer, P., Ziska, F., Quack, B., Krüger, K., Tegtmeier, S., Atlas, E., Sala, S., Engel, A., Bönisch, H., Keber, T., Oram, D., Mills, G., Ordóñez, C., Saiz-Lopez, A., Warwick, N., Liang, Q., Feng, W., Moore, F., Miller, B. R., Marécal, V., Richards, N. A. D., Dorf, M., and Pfeilsticker, K.: Evaluating global emission inventories of biogenic bromocarbons, Atmos. Chem. Phys. Discuss., 13, 12485-12539, doi:10.5194/acpd-13-12485-2013, 2013.

Huber, P. J.: Robust estimation of location parameter, Ann. Math. Stat., 35, 73-101, doi:10.1214/aoms/1177703732, 1964.

Hughes, C., Chuck, A. L., Rossetti, H., Mann, P. J., Turner, S. M., Clarke, A., Chance, R., and Liss, P. S.: Seasonal cycle of seawater bromoform and dibromomethane concentrations in a coastal bay on the western Antarctic Peninsula, Glob. Biogeochem. Cy., 23, Gb2024, doi:10.1029/2008gb003268, 2009.

Hughes, C., Franklin, D. J., and Malin, G.: Iodomethane production by two important marine cyanobacteria: Prochlorococcus marinus (ccmp 2389) and Synechococcus sp (ccmp 2370), Mar. Chem., 125, 19-25, doi:10.1016/j.marchem.2011.01.007, 2011.

Johnson, M. T.: A numerical scheme to calculate temperature and salinity dependent air-water transfer velocities for any gas, Ocean Sci., 6, 913-932, doi:10.5194/os-6-913-2010, 2010.

Jones, C. E., Andrews, S. J., Carpenter, L. J., Hogan, C., Hopkins, F. E., Laube, J. C., Robinson, A. D., Spain, T. G., Archer, S. D., Harris, N. R. P., Nightingale, P. D., O’Doherty, S. J., Oram, D. E., Pyle, J. A., Butler, J. H., and Hall, B. D.: Results from the first national UK inter-laboratory calibration for very short-lived halocarbons, Atmos. Meas. Tech., 4, 865-874, doi:10.5194/amt4-865-2011, 2011.

Kerkweg, A., Jöckel, P., Warwick, N., Gebhardt, S., Brenninkmeijer, C. A. M., and Lelieveld, J.: Consistent simulation of bromine chemistry from the marine boundary layer to the stratosphere - Part 2: Bromocarbons, Atmos. Chem. Phys., 8, 5919-5939, doi:10.5194/acp-8-5919-2008, 2008.

Kettle, H. and Merchant, C. J.: Systematic errors in global air-sea $\mathrm{CO}_{2}$ flux caused by temporal averaging of sea-level pressure, Atmos. Chem. Phys., 5, 1459-1466, doi:10.5194/acp-5-1459-2005, 2005. 
Ko, M. K. W., Poulet, G., Blake, D. R., Boucher, O., Burkholder, J. H., Chin, M., Cox, R. A., George, C., Graf, H.-F., Holton, J. R., Jacob, D. J., Law, K. S., Lawrence, M. G., Midgley, P. M., Seakins, P. W., Shallcross, D. E., Strahan, S. E., Wuebbles, D. J., and Yokouchi, Y.: Very short-lived halogen and sulfur substances, in: Scientific assessment of ozone depletion: 2002, Global Ozone Res. Monit. Proj. Rep.47, World Meteorol. Org., Geneva, 2.1-2.57, 2003

Krüger, K. and Quack, B.: Introduction to special issue: the TransBrom Sonne expedition in the tropical West Pacific, Atmos. Chem. Phys. Discuss., 12, 1401-1418, doi:10.5194/acpd-121401-2012, 2012.

Laturnus, F., Adams, F. C., and Wiencke, C.: Methyl halides from Antarctic macro algae, Geophys. Res. Lett., 25, 773-776, doi:10.1029/98g100490, 1998.

Liang, Q., Stolarski, R. S., Kawa, S. R., Nielsen, J. E., Douglass, A. R., Rodriguez, J. M., Blake, D. R., Atlas, E. L., and Ott, L. E.: Finding the missing stratospheric Bry: a global modeling study of $\mathrm{CHBr}_{3}$ and $\mathrm{CH}_{2} \mathrm{Br}_{2}$, Atmos. Chem. Phys., 10, 2269-2286, doi:10.5194/acp-10-2269-2010, 2010.

Liss, P. S. and Merlivat, L.: Air-sea gas exchange rates: Introduction and synthesis, in: The role of air-sea exchange in geochemical cycling, edited by: Buat-Ménard, P., D. Reidel, Hingham, Mass., 113-129, 1986

Liu, Y., Yvon-Lewis, S. A., Hu, L., Salisbury, J. E., and O'Hern, J. E.: $\mathrm{CHBr}_{3}, \mathrm{CH}_{2} \mathrm{Br}_{2}$, and $\mathrm{CHClBr}_{2}$ in U.S. Coastal waters during the Gulf of Mexico and East Coast carbon cruise, J. Geophys. Res., 116, C10004, doi:10.1029/2010JC006729, 2011.

Manley, S. L. and Dastoor, M. N.: Methyl-iodide $\left(\mathrm{CH}_{3} \mathrm{I}\right)$ production by kelp and associated microbes, Mar. Biol., 98, 477-482, doi:10.1007/bf00391538, 1988.

Manley, S. L. and dela Cuesta, J. L.: Methyl iodide production from marine phytoplankton cultures, Limnol. Oceanogr., 42, 142-147, 1997.

Manley, S. L., Goodwin, K., and North, W. J.: Laboratory production of bromoform, methylene bromide, and methyl-iodide by macro algae and distribution in near-shore southern California waters, Limnol. Oceanogr., 37, 1652-1659, 1992.

McFiggans, G., Plane, J. M. C., Allan, B. J., Carpenter, L. J., Coe, H., and O'Dowd, C.: A modeling study of iodine chemistry in the marine boundary layer, J. Geophys. Res.-Atmos., 105, 1437114385, doi:10.1029/1999jd901187, 2000.

Minas, H. J., Packard, T. T., Minas, M., and Coste, B.: An analysis of the production-regeneration system in the coastal upwelling area off NW Africa based on oxygen, nitrate and ammonium distributions, J. Mar. Res., 40, 615-641, 1982.

Montzka, S. A. and Reimann, S.: Ozone-depleting substances and related chemicals, in, Scientific Assessment of Ozone Depletion: 2010, Global Ozone Research and Monitoring Project - Report No. 52, Chapt. 1, edited by: World Meteorological Project, Geneva Switzerland, 2011.

Moore, R. M. and Zafiriou, O. C.: Photochemical production of methyl-iodide in seawater, J. Geophys. Res.-Atmos., 99, 1641516420, doi:10.1029/94jd00786, 1994.

Moore, R. M., Geen, C. E., and Tait, V. K.: Determination of Henry law constants for a suite of naturally-occurring halogenated methanes in seawater, Chemosphere, 30, 1183-1191, doi:10.1016/0045-6535(95)00009-w, 1995a.
Moore, R. M., Tokarczyk, R., Tait, V. K., Poulin, M., and and Geen, C. E.: Marine phytoplankton as a natural source of volatile organohalogens, in: Naturally-produced organohalogens, edited by: Grimvall, A., and deLeer, E. W. B., Kluwer Academic Publishers, D., 283-294, 1995b.

Nightingale, P. D., Malin, G., and Liss, P. S.: Production of chloroform and other low-molecular-weight halocarbons by some species of macro algae, Limnol. Oceanogr., 40, 680-689, 1995.

Nightingale, P. D., Malin, G., Law, C. S., Watson, A. J., Liss, P. S., Liddicoat, M. I., Boutin, J., and Upstill-Goddard, R. C.: In situ evaluation of air-sea gas exchange parameterizations using novel conservative and volatile tracers, Glob. Biogeochem. Cy., 14, 373-387, 2000.

O’Brien, L. M., Harris, N. R. P., Robinson, A. D., Gostlow, B., Warwick, N., Yang, X., and Pyle, J. A.: Bromocarbons in the tropical marine boundary layer at the Cape Verde Observatory - measurements and modelling, Atmos. Chem. Phys., 9, 9083-9099, doi:10.5194/acp-9-9083-2009, 2009.

Ordóñez, C., Lamarque, J.-F., Tilmes, S., Kinnison, D. E., Atlas, E. L., Blake, D. R., Sousa Santos, G., Brasseur, G., and Saiz-Lopez, A.: Bromine and iodine chemistry in a global chemistry-climate model: description and evaluation of very short-lived oceanic sources, Atmos. Chem. Phys., 12, 1423-1447, doi:10.5194/acp12-1423-2012, 2012.

Orlikowska, A. and Schulz-Bull, D. E.: Seasonal variations of volatile organic compounds in the coastal Baltic sea, Environ. Chem., 6, 495-507, doi:10.1071/en09107, 2009.

Palmer, C. J. and Reason, C. J.: Relationships of surface bromoform concentrations with mixed layer depth and salinity in the tropical oceans, Glob. Biogeochem. Cy., 23, Gb2014, doi:10.1029/2008gb003338, 2009.

Penkett, S. A., Jones, B. M. R., Rycroft, M. J., and Simmons, D. A.: An interhemispheric comparison of the concentrations of bromine compounds in the atmosphere, Nature, 318, 550-553, doi:10.1038/318550a0, 1985.

Pyle, J. A., Ashfold, M. J., Harris, N. R. P., Robinson, A. D., Warwick, N. J., Carver, G. D., Gostlow, B., O’Brien, L. M., Manning, A. J., Phang, S. M., Yong, S. E., Leong, K. P., Ung, E. H., and Ong, S.: Bromoform in the tropical boundary layer of the Maritime Continent during OP3, Atmos. Chem. Phys., 11, 529-542, doi:10.5194/acp-11-529-2011, 2011.

Quack, B. and Wallace, D. W. R.: Air-sea flux of bromoform: Controls, rates, and implications, Glob. Biogeochem. Cy., 17, 1023, doi:10.1029/2002gb001890, 2003.

Quack, B., Atlas, E., Petrick, G., Stroud, V., Schauffler, S., and Wallace, D. W. R.: Oceanic bromoform sources for the tropical atmosphere, Geophys. Res. Lett., 31, L23s05, doi:10.1029/2004g1020597, 2004.

Quack, B., Atlas, E., Petrick, G., and Wallace, D. W. R.: Bromoform and dibromomethane above the Mauritanian upwelling: Atmospheric distributions and oceanic emissions, J. Geophys. Res.Atmos., 112, D09312, doi:10.1029/2006jd007614, 2007a.

Quack, B., Peeken, I., Petrick, G., and Nachtigall, K.: Oceanic distribution and sources of bromoform and dibromomethane in the Mauritanian upwelling, J. Geophys. Res.-Oceans, 112, C10006, doi:10.1029/2006jc003803, 2007b.

Richter, U. and Wallace, D. W. R.: Production of methyl iodide in the tropical Atlantic Ocean, Geophys. Res. Lett., 31, L23s03, doi:10.1029/2004g1020779, 2004. 
Salawitch, R. J., Weisenstein, D. K., Kovalenko, L. J., Sioris, C. E., Wennberg, P. O., Chance, K., Ko, M. K. W., and McLinden, C. A.: Sensitivity of ozone to bromine in the lower stratosphere, Geophys. Res. Lett., 32, L05811, doi:10.1029/2004g1021504, 2005.

Schott, F. A., Dengler, M., and Schoenefeldt, R.: The shallow overturning circulation of the indian ocean, Prog. Oceanogr., 53, 57103, doi:10.1016/s0079-6611(02)00039-3, 2002.

Sinnhuber, B.-M. and Folkins, I.: Estimating the contribution of bromoform to stratospheric bromine and its relation to dehydration in the tropical tropopause layer, Atmos. Chem. Phys., 6, 4755-4761, doi:10.5194/acp-6-4755-2006, 2006.

Sinnhuber, B.-M., Sheode, N., Sinnhuber, M., Chipperfield, M. P., and Feng, W.: The contribution of anthropogenic bromine emissions to past stratospheric ozone trends: a modelling study, Atmos. Chem. Phys., 9, 2863-2871, doi:10.5194/acp-9-2863-2009, 2009.

Sive, B. C., Varner, R. K., and Mao, H.: A large terrestrial source of methyl iodide, Geophys. Res. Lett., 34, L17808, doi:10.1029/2007GL030528, 2007.

Smith, W. O. and Nelson, D. M.: Phytoplankton bloom produced by a receding ice edge in the Ross Sea - spatial coherence with the density field, Science, 227, 163-166, doi:10.1126/science.227.4683.163, 1985.

Smythe-Wright, D., Boswell, S. M., Breithaupt, P., Davidson, R. D., Dimmer, C. H., and Diaz, L. B. E.: Methyl iodide production in the ocean: Implications for climate change, Glob. Biogeochem. Cy., 20, Gb3003, doi:10.1029/2005gb002642, 2006.

Solomon, S., Garcia, R. R., and Ravishankara, A. R.: On the role of iodine in ozone depletion, J. Geophys. Res.-Atmos., 99, 2049120499, doi:10.1029/94jd02028, 1994.

Sturges, W. T., Oram, D. E., Carpenter, L. J., Penkett, S. A., and Engel, A.: Bromoform as a source of stratospheric bromine, Geophys. Res. Lett., 27, 2081-2084, doi:10.1029/2000gl011444, 2000.

Tegtmeier, S., Krüger, K., Quack, B., Atlas, E. L., Pisso, I., Stohl, A., and Yang, X.: Emission and transport of bromocarbons: from the West Pacific ocean into the stratosphere, Atmos. Chem. Phys., 12, 10633-10648, doi:10.5194/acp-12-10633-2012, 2012.

Tegtmeier, S., Krüger, K., Quack, B., Atlas, E., Blake, D. R., Boenisch, H., Engel, A., Hepach, H., Hossaini, R., Navarro, M. A., Raimund, S., Sala, S., Shi, Q., and Ziska, F.: The contribution of oceanic methyl iodide to stratospheric iodine, Atmos. Chem. Phys. Discuss., 13, 11427-11471, doi:10.5194/acpd-13-114272013, 2013.

Tokarczyk, R. and Moore, R. M.: Production of volatile organohalogens by phytoplankton cultures, Geophys. Res. Lett., 21, 285288, doi:10.1029/94g100009, 1994.
Vogt, R., Sander, R., Von Glasow, R., and Crutzen, P. J.: Iodine chemistry and its role in halogen activation and ozone loss in the marine boundary layer: A model study, J. Atmos. Chem., 32, 375-395, doi:10.1023/a:1006179901037, 1999.

von Glasow, R.: Atmospheric chemistry - sun, sea and ozone destruction, Nature, 453, 1195-1196, doi:10.1038/4531195a, 2008.

von Glasow, R., von Kuhlmann, R., Lawrence, M. G., Platt, U., and Crutzen, P. J.: Impact of reactive bromine chemistry in the troposphere, Atmos. Chem. Phys., 4, 2481-2497, doi:10.5194/acp-42481-2004, 2004.

Wanninkhof, R.: Relationship between wind-speed and gasexchange over the ocean, J. Geophys. Res.-Oceans, 97, 73737382, doi:10.1029/92jc00188, 1992.

Wanninkhof, R. and McGillis, W. R.: A cubic relationship between air-sea $\mathrm{CO}_{2}$ exchange and wind speed, Geophys. Res. Lett., 26, 1889-1892, doi:10.1029/1999g1900363, 1999.

Warneck, P. and Williams, J.: The atmospheric chemist's companion-numerical data for use in the atmospheric sciences, Springer Science+Business Media B.V., 2012.

Warwick, N. J., Pyle, J. A., Carver, G. D., Yang, X., Savage, N. H., O'Connor, F. M., and Cox, R. A.: Global modeling of biogenic bromocarbons, J. Geophys. Res.-Atmos., 111, D24305, doi:10.1029/2006jd007264, 2006.

Williams, J., Gros, V., Atlas, E., Maciejczyk, K., Batsaikhan, A., Scholer, H. F., Forster, C., Quack, B., Yassaa, N., Sander, R., and Van Dingenen, R.: Possible evidence for a connection between methyl iodide emissions and Saharan dust, J. Geophys. Res.-Atmos., 112, D07302, doi:10.1029/2005jd006702, 2007.

Yamamoto, H., Yokouchi, Y., Otsuki, A., and Itoh, H.: Depth profiles of volatile halogenated hydrocarbons in seawater in the Bay of Bengal, Chemosphere, 45, 371-377, doi:10.1016/s00456535(00)00541-5, 2001.

Yokouchi, Y., Mukai, H., Yamamoto, H., Otsuki, A., Saitoh, C., and Nojiri, Y.: Distribution of methyl iodide, ethyl iodide, bromoform, and dibromomethane over the ocean (east and Southeast Asian seas and the western pacific), J. Geophys. Res.-Atmos., 102, 8805-8809, doi:10.1029/96jd03384, 1997.

Yokouchi, Y., Hasebe, F., Fujiwara, M., Takashima, H., Shiotani, M., Nishi, N., Kanaya, Y., Hashimoto, S., Fraser, P., ToomSauntry, D., Mukai, H., and Nojiri, Y.: Correlations and emission ratios among bromoform, dibromochloromethane, and dibromomethane in the atmosphere, J. Geophys. Res.-Atmos., 110, D23309, doi:10.1029/2005jd006303, 2005.

Yokouchi, Y., Osada, K., Wada, M., Hasebe, F., Agama, M., Murakami, R., Mukai, H., Nojiri, Y., Inuzuka, Y., Toom-Sauntry, D., and Fraser, P.: Global distribution and seasonal concentration change of methyl iodide in the atmosphere, J. Geophys. Res.Atmos., 113, D18311, doi:10.1029/2008jd009861, 2008. 